\title{
Paisajes urbanos de la industria Apropiaciones estéticas y conservación patrimonial
}

\author{
ÁNGELES LAYUNO ROSAS \\ Profesora de Teoría e Historia de la Arquitectura. Escuela de Arquitectura \\ Universidad de Alcalá \\ angeles.layuno@uah.es
}

\begin{abstract}
Resumen
En las últimas décadas la definición de paisaje urbano industrial plantea una realidad ambigua y controvertida cuando se trata de definir procesos de patrimonialización de bienes inmuebles e instalaciones que han configurado históricamente determinadas áreas de la ciudad contemporánea. Las construcciones de la industria y la obra pública desde el siglo XIX centraron los debates sobre el impacto de su inserción en la realidad de la ciudad y el paisaje de cada momento, siendo instrumentalizados como modelos lingüísticos y conceptuales de la arquitectura moderna, convertidos primero en objetos míticos del credo funcionalista, y posteriormente en bienes dignos de conservación patrimonial. El objetivo de este trabajo consiste en analizar, a través de diversas fuentes y ejemplos, las sucesivas percepciones y valoraciones mutables en el tiempo y el espacio que han experimentado los bienes y paisajes de la industria fundamentalmente a lo largo de los siglos XIX y XX, reflejadas en aproximaciones estéticas, urbanísticas y patrimoniales.
\end{abstract}

Palabras clave: Arquitectura Contemporánea; Paisaje; Patrimonio Industrial. 


\title{
Landscapes of industry. Aesthetic apropriations and heritage conservation
}

\begin{abstract}
In recent decades, the definition of industrial urban landscape presents an ambiguous and controversial reality when it comes to defining heritage processes of industrial buildings and structures associated with the productive sector that historically have shaped certain areas of the contemporary city. From the nineteenth century on, the structures of industry and those related to public works were the aim of debates about their integration into the reality of the city, the landscape and the architecture of their time, finally being orchestrated as linguistic and conceptual models of the modern architecture, converted first into mythical icons of functional style of Modern Movement and later in real worthy of historic preservation. The aim of this paper is to analyze, through various sources and examples, the mutable in time and space perceptions and assessments that have experienced heritage and industrial landscapes along the nineteenth and twentieth centuries, appropriations reflected in aesthetic, urban and heritage fields.
\end{abstract}

Key words: Contemporary Architecture; Landscape; Industrial Heritage.

Sumario: 1.-Introducción. 2.- De la repulsa a la mitificación del edificio y el paisaje industrial. 2.1.- El mito de la máquina y la génesis de la arquitectura moderna. 3.- La imagen y los efectos de la desindustrialización. 4.- Refuncionalización. 5.Conclusiones. 6.- Bibliografía.

\section{Introducción.}

La Revolución Industrial ocasionó de manera masiva la formación de áreas urbanas y colonias destinadas a la industria, generando en algunos lugares un "paisaje-tipo" vinculado a la modificación morfológica, ambiental e iconográfica de las ciudades.

Los paisajes urbanos industriales constituyen una herencia de las funciones urbanas de la ciudad, y posibilitan el análisis de su cualidad como producto cultural derivado de los usos económicos asumidos a lo largo de la 
historia o en un momento determinado del tiempo (Capel, 2002: 67-69), por ello su investigación y su tratamiento cultural y patrimonial deben partir de un planteamiento conceptual derivado de su historicidad y de un análisis diacrónico del medio, desde su formación a su posible refuncionalización, asumiendo en cada caso problemáticas diversas.

\section{De la repulsa a la mitificación del edificio y el paisaje industrial.}

La influyente crítica que generaron los organismos urbanos aniquilantes y distorsionadores de las formas de vida preindustriales vinculadas a los modos de producción artesanales y a los medios de vida rurales en la génesis de la ciudad industrial (Seta, 2002: 243-269), determinó, sobre todo en Inglaterra y Francia, la proliferación durante el siglo XIX de propuestas de reformadores sociales y filántropos que reaccionaron ante los desaciertos que en el medio urbano y social estaba provocando la expansión e implantación masiva del sistema de producción capitalista (Choay, 1983: 18-20). Pensadores y políticos como Engels, Marx, Fourier, Proudhon, Carlyle, Fourier, Considérant, Ruskin, Pugin, Robert Owen o Morris enarbolaron una crítica a la "ciudad industrial" existente y plantearon en muchos casos nuevas fórmulas ideológicas, funcionales y morfológicas que constituyeron las bases de las colonias y ciudades creadas para la industria ideadas como utópicos emplazamientos idílicos situados en el curso de los ríos frente a la imagen urbana del suburbio fabril de la máquina de vapor humeante y degradado a todos los niveles (Danesi, 1976: 16-23)1. Con una fuerte impronta paternalista, se promoverá una mejora del hábitat, del equipamiento y el espacio público encubriendo en el fondo la búsqueda de la máxima rentabilidad de la producción mediante el control sistemático de los espacios y tiempos de los individuos, la homogeneización de las mentalidades, y la racionalización de los itinerarios y los espacios en los que se desarrollaban los procesos humanosy mecánicos. culmina en el brillante planteamiento que realiza Tony Garnier en su Ciudad

\footnotetext{
${ }^{1}$ Un interesante estudio de las colonias industriales del siglo XIX desde sus supuestos filosóficos es el llevado a cabo por Danesi (1976: 16-23), donde analiza en profundidad el pensamiento de William Morris.
} 
Industrial, sentando las bases, junto con el movimiento de las ciudades-jardín dirigido por Ebenezer Howard, de la ideología urbana del Movimiento Moderno. La imagen racional y moderna de la Ciudad Industrial de Tony Garnier, publicada en 1917 pero concebida durante su pensionado en Roma en 1904, representaba la culminación de las utopías positivistas del siglo anterior mostrando principios comunes a otras propuestas como la diversificación industria-agricultura como base de desarrollo, la zonificación estricta de los espacios urbanos regulados por vías de comunicación y criterios higiénicos, la presencia de parques y áreas de esparcimiento, y la satisfacción de servicios para el obrero-agricultor, a los que sumar la racionalidad en la concepción del urbanismo y la arquitectura, armonizando ideas clásicas y modernas, junto a metáforas tecnológicas del lenguaje de la industria (Garnier, 1990).

Las atractivas láminas y el propio texto de Garnier representaban además un potente contrapunto del paisaje urbano industrial que presidió los tiempos más duros de la Revolución Industrial, cuya imagen fue transmitida con todo realismo a través de la descripción literaria que Charles Dickens realiza de la ya mítica Coketown en su novela Tiempos Difíciles (1854):

(...) era una ciudad de ladrillos rojos, o mejor, de ladrillos que hubieran sido rojos si el humo y la ceniza se lo hubiesen permitido; tal como estaban las cosas, era una ciudad de un rojo y negro natural, como la cara pintada de un salvaje. Era una ciudad de máquinas y altas chimeneas, de las que salían, sin solución de continuidad, interminables serpientes de humo que jamás llegaban a desvanecerse. Tenía un canal negro, un río de color púrpura por los barnices malolientes, y grandes grupos de edificios, llenos de ventanas, donde durante todo el día había un continuo golpear y trepidar, donde los émbolos de las máquinas de vapor se movían arriba y abajo...

(...) Parecía que toda la ciudad se friera en aceite. Por todas partes había un olor insoportable a aceite hirviendo. El aceite daba brillo a las máquinas, ensuciaba la ropa de los hombres, corría y goteaba de los muchos pisos de las fábricas. La atmósfera de estos palacios de hadas se parecía al soplo del simún, $y$ sus habitantes, jadeando por el calor, avanzaban fatigosamente en el desierto (...) (Benévolo, 1990: 159). 
Los párrafos de Dickens, repletos de evocaciones sensoriales, producen una inmersión ambiental que nos alerta del verdadero alcance de la industrialización masiva, desde el paisaje urbano al hábitat del obrero. Sus descripciones reflejan una cuestión esencial, la contaminación del ritmo de la máquina al ritmo de la ciudad industrial, como será captado por los mecanismos del cine sonoro. La literatura de Dickens poseía además un correlato en el contexto real, socio-económico, político e ideológico de su época, las décadas centrales del siglo XIX, azotadas por las nefastas consecuencias de la aplicación a la economía de las teorías liberales de Adam Smith, denunciadas por Friedrich Engels en La situación de la clase obrera en Inglaterra (1845). Aproximadamente un siglo más tarde, el historiador, sociólogo y urbanista Lewis Mumford en su obra La ciudad en la historia. Sus orígenes, transformaciones y perspectivas (1961), describía el carácter alienante y deshumanizador de las primeras ciudades o áreas industriales, en que el capitalismo había producido el medio urbano más degradado de la historia:

(...) la producción fabril a gran escala transformó las ciudades industriales en oscuras colmenas que diligentemente resoplaban, rechinaban, chillaban y humeaban durante doce y catorce horas al día, a veces sin interrupción en toda la jornada (...) Como testigos de la inmensa productividad de la máquina, los montones de escoria y de basura alcanzaban la dimensión de montañas, en tanto que los seres humanos cuyo trabajo hacía posible estos logros eran mutilados y muertos casi con tanta rapidez como lo hubieran sido en campos de batalla... Los agentes generadores de la nueva ciudad fueron la mina, la fábrica y el ferrocarril... En todos los sectores los principios anteriores de educación aristocrática y cultura rural se veían reemplazados por una devoción exclusiva al poder industrial y al éxito pecuniario, disfrazados a veces de democracia (Mumford, 2012: 741-742).

En el fondo de estos textos y en las propuestas de ciudades y colonias anteriormente citadas, subyacía el problema del antagonismo entre las de vida del campo y las de la ciudad, y la amenaza latente que sobre el mundo de la naturaleza como anhelo ideológico representaba la máquina. Una vez producido el triunfo de la mecanización de la metrópoli, las posturas ideológicas de los siglos XIX y XX desplegarán diversos matices entre el rechazo y la aceptación exaltada del maquinismo. 
La obra de Mumford recrea con gran interés literario los impactos medioambientales de este escenario urbano, ofreciendo datos de la inmundicia y falta de higiene, de la convivencia de hombres con basuras y animales, de la ausencia de espacios abiertos públicos, de vegetación o huertos, de las penosas condiciones de habitabilidad, o la falta de infraestructuras, un tenebroso paisaje urbano y humano que fue captado gráficamente en los grabados del artista francés Gustave Doré ilustrativos de la obra de Blanchard Jerrold, London: A Pilgrimage (1872). Doré representa una fuente gráfica excepcional de la degradada situación de la clase obrera con sus asentamientos inicialmente emplazados sin ningún criterio de planificación lógica en los espacios intersticiales remanentes entre las fábricas y las líneas del ferrocarril (Fig. 1). No obstante, para la mentalidad de los emprendedores del S. XIX, el impacto ecológico era el precio a pagar en nombre de la riqueza, los beneficios y el progreso, pues donde había "suciedad" había también “dinero" (Tandy, 1979: 28)².

\footnotetext{
2 Situación que por su insostenibilidad daría paso a la denominada por Patrick Geddes fase neotécnica en que el vapor es sustituido por la electricidad como fuente de energía, impulsándose los avances científicos en higiene, obras públicas e infraestructuras urbanas como los sistemas de alcantarillado, agua potable, ligadas a reformas urbanísticas para "humanizar" la ciudad industrial, siguiendo los lemas del aire puro, sol, vegetación enarbolados por el Movimiento Moderno (Mumford, 2012: 796). Estos cambios estuvieron acompañados por un imparable proceso de investigación en nuevas fórmulas de habitabilidad para la clase obrera que caracterización la arquitectura moderna.
} 


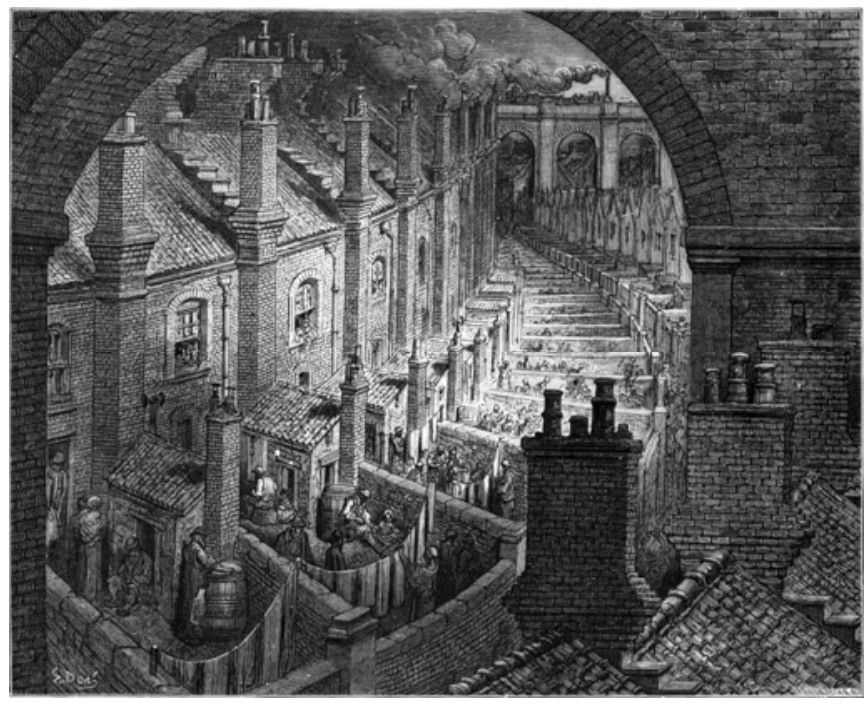

Fig. 1: Gustave Doré: Over London by Rail (London: A pilgrimage, 1872)

En el campo de la cultura arquitectónica, en la propia Inglaterra la problemática causada por la ciudad industrial se expresaba abiertamente en las tendencias conservadoras vinculadas al apogeo del gothic revival, tendencia que teñida de afirmación nacionalista, moral y religiosa llega incluso a salpicar la "piel" de los mismos edificios industriales a través del uso de elementos historicistas sancionadores de un género de arquitectura aún no valorado culturalmente. La crítica al avance imparable de la industrialización capitalista estuvo asociada a una igualmente trascendente reacción nostálgica hacia las formas de vida preindustriales, potenciando una reflexión ante una realidad urbana que se estaba transformando económica, social y morfológicamente de manera imparable. Reacción romántica que se desató desde los distintos campos de la cultura y que queda contenida en las siguientes palabras de John Ruskin y su labor crítica contra los avances de la sociedad industrial y sus productos técnicos:

Intentaremos hacer bello, pacífico y fértil un pequeño trozo de territorio inglés. No tendremos máquinas de vapor ni ferrocarril; ni criaturas abandonadas sin cariño o sin cuidado, ni otros miserables que los enfermos, ni otros ociosos que los muertos. No tendremos libertad, sino obediencia inmediata a la ley reconocida y a las personas elegidas; no igualdad, sino reconocimiento de toda superioridad y rechazo de toda bajeza...(...) Cuando debamos ir a algún sitio, iremos tranquila y seguramente, no a cuarenta millas por hora con el riesgo de la vida; cuando debamos transportar algo, lo haremos sobre la espalda de animales, 
cuando debamos transportar algo, lo haremos sobre la espalda de animales, o incluso sobre la nuestra, en carros o en barcas; tendremos abundantes hierbas y flores en nuestros jardines y grano en los campos; pero pocos ladrillos....Poco a poco se desarrollará entre nosotros algún arte más elevado y surgirá algún débil rayo de ciencia. Algo de botánica, pero lo bastante humilde como para poner en discusión la existencia de las flores; un poco de historia, pero lo bastante sencilla como para no plantearse el origen del hombre (Fusco, 1976: 34-35).

En la misma línea que evidencia un siglo plagado de dramática lucha ideológica entre progreso y tradición, su colega A. W. Pugin en su afán de regeneración moral de la sociedad ofrecía su particular contraposición maniquea -también visual- entre la idealizada ciudad preindustrial medieval y la nociva ciudad industrial en su obra Contrasts. Or a parallel between the noble edifixes of the Middle Ages, and corresponding buildings of the present day, showing the Decay of Taste (1836).

Paralelamente en la fase paleotécnica de la Revolución Industrial existió también una visión positiva y positivista, incluso sublime de la técnica y la industria. La Exposición Universal de Londres celebrada en 1851 y sus sucesivas convocatorias reforzarían el elogio y la exaltación de la industria y el progreso tecnológico, naciendo pronto una aceptación de las transformaciones urbanas y territoriales producidas por la máquina de vapor y el ferrocarril responsables de un paisaje urbano caracterizado por las altas chimeneas y el humo de las fábricas, las estructuras descarnadas de los gasómetros y las líneas del ferrocarril.

Por otro lado, desde el siglo XVIII, la relativización del gusto influyó en la representación de nuevos motivos de paisaje implicados en las categorías de lo sublime y lo pintoresco, como era el caso de los temas industriales. Como señala Gillian Darley, el paisaje de Coalbrookdale, convertido desde 1750 en algo semejante a la fragua de Vulcano, con calderas de fundición, enormes cubas y altos hornos que vomitaban humo y llamas, brillando contra el cielo nocturno, atraía a numerosos pintores, narradores y viajeros de la época (Darley, 2010: 33). Esta imagen es la representada en el óleo de W. Williams Afternoon view of Coalbrookdale (1777), donde la naturaleza envuelta en humo y llamas como producto de la incesante actividad de las fundiciones ocupa el paisaje del fondo del valle del río Severn siendo contemplado plácidamente 
desde una colina situada en primer plano por un grupo de aristócratas terratenientes ${ }^{3}$.

En Inglaterra fueron a menudo los propios industriales quienes se esforzaron por paliar los efectos de la industria en el territorio dentro de la tendencia que William Gilpin definió como una categoría opuesta a la belleza clásica con el término de "pintoresco" (Maderuelo, 2004). La fábrica como complemento pintoresco de la casa de campo se contempla en uno de los Libros Rojos del arquitecto paisajista Humphry Repton, fruto del encargo del empresario textil Benjamin Gott quien buscaba la remodelación paisajística de su mansión y posesión campestre situada en las proximidades de Leeds, la Armley House y su entorno, incluyendo la Armley Mill, su factoría recién reformada. En estos libros, Repton buscaba establecer los principios del arte de diseñar el terreno a través de un sistema de vistas superpuestas donde las láminas grabadas mostrarían el antes y el después de la intervención artificial sobre el paisaje. Repton había recibido encargos de trabajos paisajistas en las periferias urbanas o espacios próximos a centros industriales como Bristol, Leeds, y Londres, donde algunos industriales de su tiempo adquirieron terrenos donde ubicar casas de campo en medio de bosques y prados, lo que le permitió enfrentarse a la polémica contraposición entre dos realidades, la naturaleza no contaminada, y las fábricas de los suburbios urbanos, encarnación de la técnica y la industria, consideradas por Repton un motivo de menor belleza además de las causantes de impactos negativos en el paisaje $e^{4}$

\footnotetext{
${ }^{3}$ Existen numerosas grabados y pinturas de Coalbrookdale datadas en la segunda mitad del siglo XVIII prueba del gran interés suscitado por el lugar. Obras y documentos conservados en el Shrewsbury Museums Service (Shropshire, Inglaterra).

${ }^{4}$ Un ejemplo de esta actitud es la intervención paisajista de Humphrey Repton en Attingahm Park, Shropshire, por encargo de la familia Hill, quien construyó una mansión y un parque en las inmediaciones de su fundición siderúrgica desmantelada. Esta conciencia por el reciclaje de los terrenos de la industria abandonados, sin caer aún en el valor patrimonial, prosperó tempranamente en países con un elevado grado de industrialización como Inglaterra, donde se desarrollaron iniciativas de conversión de los antiguos terrenos dedicados a la minería del carbón en parques urbanos mediante reforestación, o siembra de semillas agrícolas sobre desechos y montículos, apareciendo los primeros espacios verdes con fines recreativos producto de la desindustrialización.
} 
Durante la segunda mitad del siglo XVIII la mayor parte de la industria británica se emplazaba en el campo, en los valles surcados por los ríos que proporcionaban la energía hidráulica para la producción, por tanto, la industria había provocado cambios notables en el territorio inglés, un país esencialmente rural. La continuidad de localizaciones pre-industriales tradicionales estaba asociada a la búsqueda de nuevos emplazamientos estratégicos en los que aprovechar las fuentes de energía, el bajo precio del suelo, a la vez que ejercer un control ideológico sobre la fuerza de trabajo. En el caso de la industria textil estos emplazamientos permitían compaginar diversos métodos de trabajo en un principio, ya que el sistema de concentración de los procesos y la mano de obra en las manufacturas no provocó la radical desaparición del sistema del putting out, consistente en que los campesinos podían realizar parte de las labores del proceso textil en sus domicilios y así compaginar el trabajo en el campo con las actividades textiles.

Este es el contexto del proyecto encargado a Repton y al cual responde la armónica integración de la fábrica textil en el paisaje rural en una de las láminas grabadas que componían las vistas de la intervención, tratándose de una propuesta no sólo estética sino ideológica. Benjamin Gott había experimentado problemas sociales en otras factorías laneras de su propiedad debido a las quejas de los habitantes a causa de los humos y olores que desprendían los tintes y talleres laneros, pero también por la marginación de ciertas formas de trabajo artesanal como las mencionadas.

En la representación de la imponente Armley Mill en forma de edificio de pisos movido por energía hidráulica, Gott buscaba limpiar su imagen y presentarse como un industrial no contaminante, suavizando los impactos al integrar casa y fábrica en un entorno rodeado de vegetación, prados y formas de economía tradicionales, sin dejar por ello de incorporar los avances técnicos más punteros en la fabricación, condiciones ambas que harían célebre la fábrica en su tiempo. su versión modificada del paisaje, la Armley Mill (1810) ocupa un lugar preeminente que realza su monumentalidad avistándose la mansión señorial de los Gott en un promontorio elevado en segundo plano (Fig. 2). La introducción de un elemento a priori discordante, la industria, supuso un reto en la solución de un paisaje pintoresco habida cuenta que el propio Repton había sido crítico con los efectos medioambientales y sociales de la masificación industrial. De ahí el interés por difuminar el skyline del plano de 
dustrial. De ahí el interés por difuminar el skyline del plano de fondo donde las chimeneas de las fábricas de Leeds se hubieran convertido en un elemento más agresivo frente al bucólico y rural escenario preindustrial protagonizado por la fábrica. De hecho, la mole de la fábrica caracteriza y crea el paisaje.

La admiración de Repton hacia la construcción industrial y su efecto en el paisaje le condujo a escribir consideraciones estilísticas y estético-ambientales sobre la misma, alabando el efectismo producido tanto de día como en el paisaje nocturno por la iluminación de gas de la fábrica, además de alabar la simplicidad de la construcción, which looks like what it is-a Mill and Manufactory; and is not disguised by Gothic windows or other architectural pretensions (Daniels, 2000: 249), compartiendo con su cliente una actitud de rechazo al historicismo en favor de una arquitectura más funcional y progresista.

Hay que considerar por otro lado este encargo como un acto cultural meditado, no tanto por la excepcionalidad del mismo, puesto que otros industriales habían actuado en semejante dirección, sino por el rango del arquitecto paisajista y del propio comitente. Una breve semblanza de Benjamin Gott lo define como un hombre sensible y polifacético comprometido con la vida pública y cultural de la ciudad, coleccionista de arte, filántropo y mecenas. La decisión de convertir la casa en residencia permanente desde 1816 y en sede de su colección de libros y obras de arte debió motivar el encargo a Repton. La Armley House y su entorno se convierte así en una manifestación de prestigio para su comitente, aspirando a reformular la imagen de Gott como caballero-mercader, con su combinación de intereses comerciales, industriales y culturales, dentro de una escenario de paternalismo territorial (Daniels, 2000: 249). 


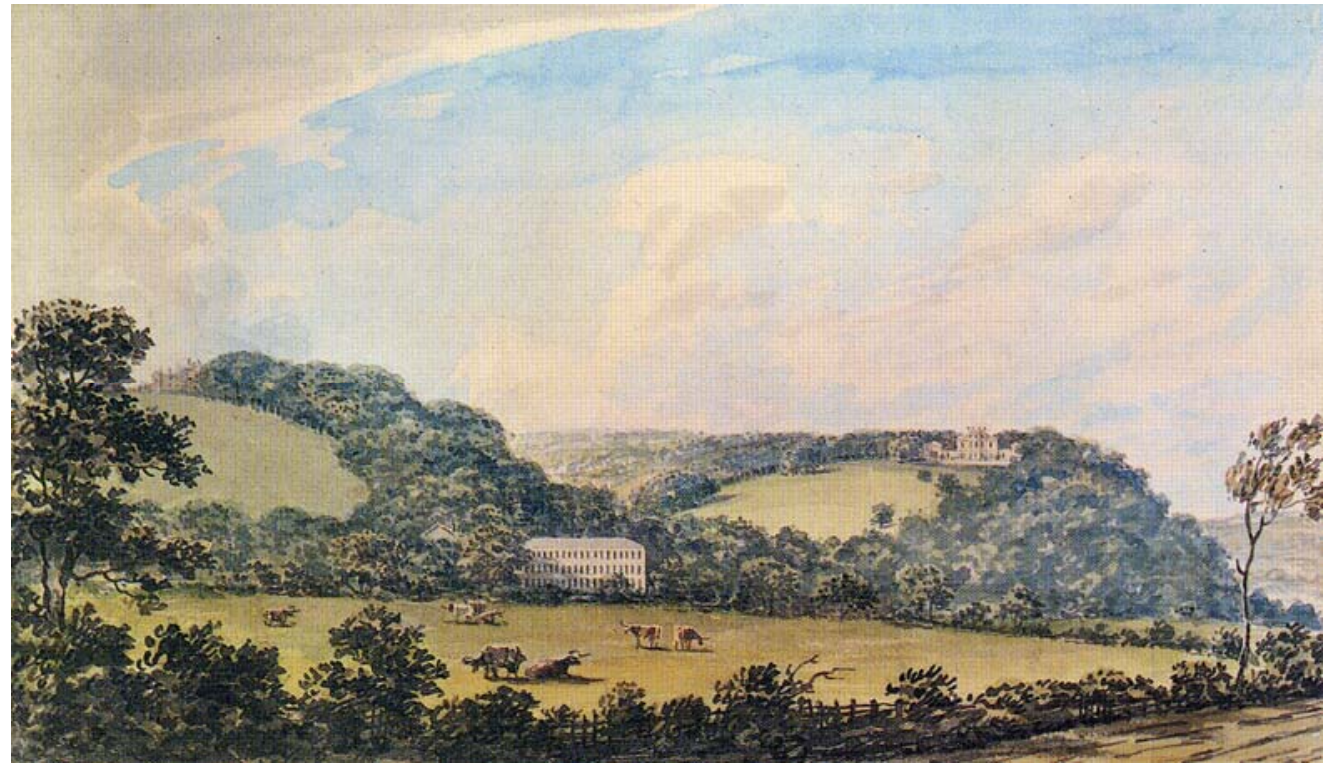

Fig. 2: Humphry Repton: Vista general procedente del Libro Rojo para la Armley House (1810) Fuente: Daniels, 2000, p. 248

\subsection{El mito de la máquina y la génesis de la arquitectura moderna.}

En las primeras décadas del siglo XX la máquina y el mundo de la industria comienzan a convertirse en un objetivo de reflexión e instrumentalización estética no sin sentido crítico, de hecho, la polémica que transita en el fondo del discurso sobre la ciudad industrial determina la continuidad de una doble tendencia ya enunciada en el siglo anterior, la tradicional oposición campo y ciudad, naturaleza y técnica por un lado, y por otro, la dual consideración de la metrópolis, como epicentro del caos y la ignominia o como fuente de nuevos estímulos para el intelecto y los sentidos. La agitación de la vida nerviosa de la metrópoli y la asimilación de los componentes tecnológicos inscritos en los paisajes urbanos modernos constituyen objetos de apropiación para la vanguardia, apareciendo una nueva sensibilidad hacia los efectos del maquinismo sobre la vida urbana en ingredientes como la velocidad, el ruido, la multiplicación de trayectorias, el gigantismo de lo construido, la extralimitación de la ciudad convencional, la presencia de la tecnología, la revolución del tiempo, o la multiplicidad de estímulos visuales, olfativos y auditivos. 
Los síntomas de un cambio de actitud hacia la ciudad industrial se vislumbran en ensayos que ensalzan las cualidades de la metrópoli coadyuvando a suscitar lo que Georg Simmel describió como el acrecentamiento de la vida nerviosa en su ensayo "Las grandes urbes y la vida del espíritu" (1903), y que August Endell reivindicaría positivamente en su ensayo "La Belleza de la

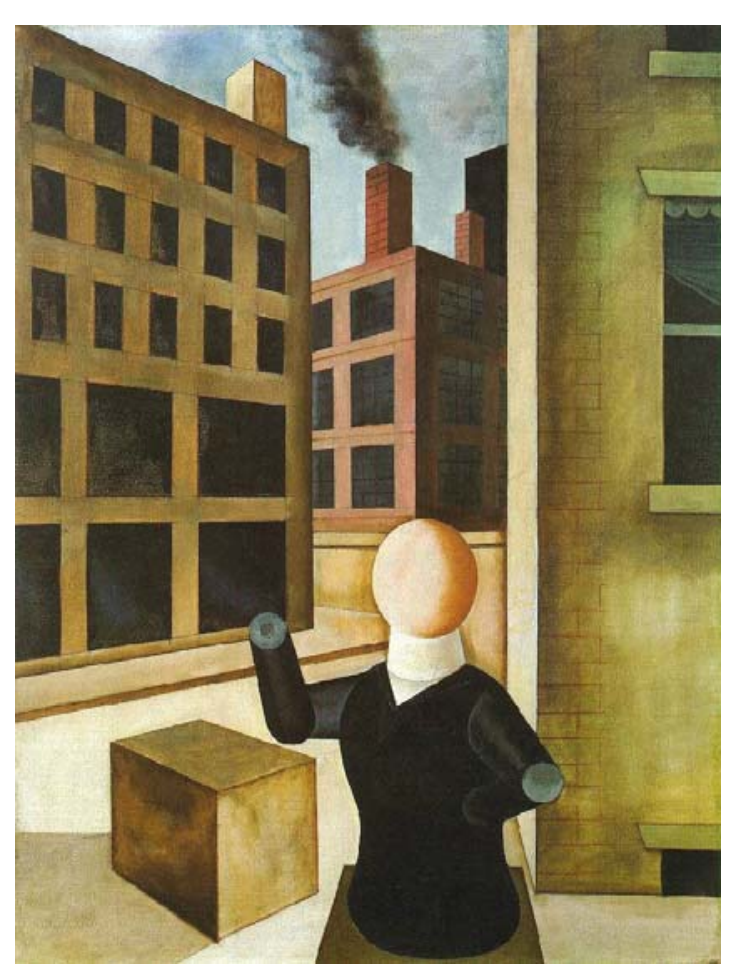
Metrópoli" (1903) (Pizza, Pla, 2002: 167-185; 181-183). Las visiones urbanas de artistas de vanguardia, ahora enriquecidas con la fotografía y el cine, se aproximan no sólo al boulevard sino también a la periferia industrial (Fig. 3), a las estaciones, almacenes y también a las fábricas (Dethier y Guiheux 1994: 67-75).

Figura 3: George Grosz. Sin título (1920). Kunstsammlung Nordrhein-Westfalen. Dusseldorf http://archivesdada.tumblr.com/page/47

La representación de la complejidad que entrañaba la ciudad industrial encontró en el medio fílmico el mejor aliado como revela la brillante obra de Walter Ruttmann Berlín, Sinfonía de una Ciudad (1927)5, adscrita a un género las sinfonías urbanas- que desde las primeras décadas del siglo aunaron lo estético y lo documental, jugando un papel determinante en la construcción de la imagen urbana (Fig. 4).

${ }^{5}$ El guión de Ruttmann se había desarrollado sobre una idea original de Carl Mayer, autor de guiones clave del expresionismo alemán como El Gabinete del Dr. Caligari. La música fue obra de Edmund Meisel y ocupa un lugar determinante en la Sinfonía de Ruttmann. 

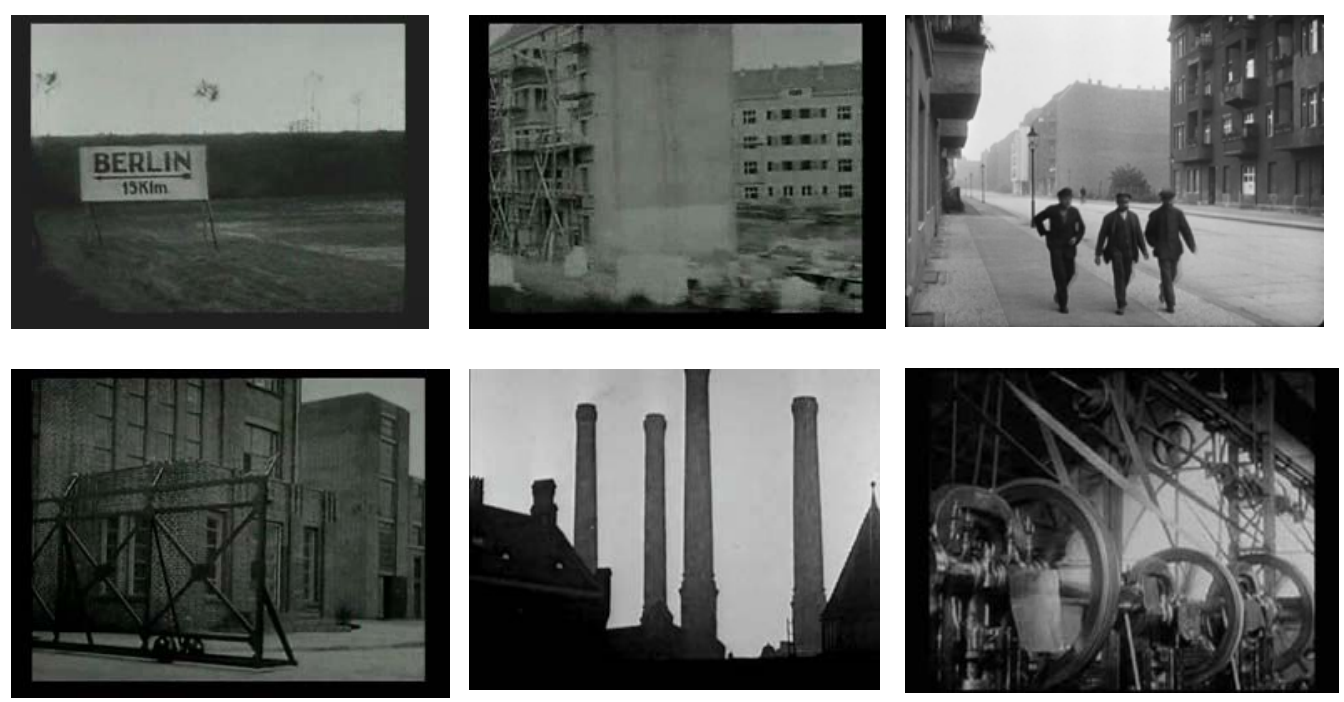

Figura 4: Walter Ruttmann: Fotogramas de Berlín, Sinfonía de la Ciudad (1927).

Al margen de los excelentes y novedosos recursos fílmicos cuyo análisis excede el contenido de este artículo, la obra de Ruttmann, tomando como escenario un día en la vida cotidiana de la ciudad, refleja las consecuencias del capitalismo industrial en las formas de vida individuales y colectivas de una ciudad como Berlín, auténtica metrópolis de la vida moderna. Pero además, lo relevante para el tema de este estudio, es la representación insistente que hace el film de Ruttmann de la industria urbana, desde los sistemas productivos de las fábricas hasta el paisaje industrial periférico, recreando musical y visualmente la contaminación del ritmo de la automatización del trabajo industrial en el ritmo de la propia vida urbana ${ }^{6}$. Las primeras secuencias del film constituyen un excepcional documento que refleja las nuevas relaciones entre ciudad y campo creadas por las aglomeraciones fabriles periféricas en torno a los ejes de transporte como el ferrocarril, mostrando la crisis del modelo de ciudad limitada y abarcable y modificando la concepción del

${ }^{6}$ Walter Benjamin apuntaba a que el cine era el medio que debía reflejar el movimiento de la metrópoli y en este sentido tanto Ruttmann y dos años después Dziga Vertov en El Hombre de la cámara de cine (1929) harán de este tema el objetivo de sus narraciones si bien con planteamientos formales y concepciones diversos, Ruttmann capta el dinamismo de la metrópoli y Vertov el dinamismo como concepto abstracto de la ciudad industrial. Véase Tupitsyn, 2002: 94. 
ciudad limitada y abarcable y modificando la concepción del espacio-tiempo de la misma, desde el centro a las periferias que se desdibujan y funden con el territorio. La naturaleza se transforma con el protagonismo de la máquina y la velocidad del medio de transporte que impacta en el territorio, dinamizando la frontera entre campo y ciudad. A una distancia de 15 kilómetros de la urbe, las imágenes humeantes de los suburbios fabriles de Berlín son captadas fugazmente a la velocidad decreciente del medio de transporte ferroviario, pasando ante nuestros ojos zonas industriales intercaladas con vivienda obrera de diversa tipología como las deplorables Mietkasernen, informando del crecimiento de la ciudad y de la nueva iconografía de las fábricas que definen su perfil, su segregación zonal y la fragmentación de la forma urbana provocada por la presencia del ferrocarril.

Por otro lado, en la Sinfonía de Ruttmann, la fábrica es un gueto dentro de la ciudad y destaca por la escala y la ocupación de suelo urbano, por sus cientos de empleados y sus procedimientos automatizados de producción cuyos movimientos mecánicos son contagiados tanto a los seres humanos que trabajan en el lugar como al ritmo mismo de la metrópoli. La Sinfonía de Berlín transmite un evidente desasosiego al tratar algunos de los ingredientes de la vida moderna en los que el expresionismo y la nueva objetividad incidirán de forma crítica, como es la cosificación del individuo, tema reflejado por el pintor George Grosz a través de maniquíes sin rostro insertos en un paisaje urbano producto de la pura razón constructiva y de la máquina.

En otro orden de cosas, la genealogía del Movimiento Moderno en arquitectura se cimentó sobre el mito del progreso representado por los edificios industriales, no sólo a nivel historiográfico, sino estético y técnicoconstructivo. La fábrica se convierte en icono de la arquitectura del siglo XX y en este proceso de construcción mítica jugaron un papel determinante las imágenes fotográficas manipuladas por artistas, arquitectos, críticos y fotógrafos, pues existió todo un corpus de textos e imágenes que configuraron en el imaginario colectivo la asociación de los productos industriales a la modernidad convirtiendo a la técnica en un poderoso medio de ideología cultural. Pero también la fábrica se convirtió en icono moderno por las propias fábricas construidas por entonces por los arquitectos modernos quienes elevaron a un nivel paradigmático la arquitectura industrial reivindicando el buen diseño arquitectónico frente a la obra de los ingenieros de siglos pasados. 
Reyner Banham, siguiendo la estela de la historiografía canónica de la modernidad7, en su obra La Atlántida de Hormigón (1986), además de analizar con detalle los modelos establecidos como génesis ideológica y formal de la arquitectura moderna, realizaba unas específicas contribuciones a la valoración patrimonial de determinados edificios y tipologías, cuyo material de construcción -el hormigón armado- se asociaba a determinados rasgos funcionales, tipológicos y formales ligados a la arquitectura industrial del S. $X X$, contribuyendo a indicar el paso de la valoración funcional a la patrimonial. Las imágenes de silos y elevadores de grano así como de algunas fábricas americanas constituían una iconografía utilizable y un lenguaje formal trasladable a la arquitectura moderna, incidiendo en que las innovaciones de los ingenieros americanos como Ernst Ransome o Albert Kahn vinculados a la industria automovilística norteamericana de las plantas de Ford en Detroit eran importantes porque América, sus edificios industriales y sus sistemas de producción simbolizan la cuna de la modernidad, como se registró en algunos de los textos de Gropius, Le Corbusier8, Eric Mendelsohn o Moisei Ginzburg (Banham, 1989).

Este proceso divulgativo es bien conocido y se inició por parte de Walter Gropius cuando emplea fotografías de fábricas de pisos de hormigón y de silos de grano para ilustrar su artículo “Die Entwicklung Moderner

\footnotetext{
${ }^{7}$ Las primeras aportaciones historiográficas del Movimiento Moderno -S. Giedion, N. Pevsner, K. Behrendt, entre otros-, fueron especialmente incidentes en la instalación de las tipologías industriales y de la vivienda obrera en el plano de la arquitectura culta. J.M. Richards en su texto The Functional Tradition (1958), así como también en algunos artículos aparecidos en la revista Architectural Review de la que era editor, reconocía el papel jugado por la arquitectura industrial de los ingenieros del siglo XIX como pionera del gusto moderno.

${ }^{8}$ Desde 1919 Le Corbusier había tomado "prestadas" las imágenes de Gropius aparecidas en el Anuario del Werkbund para sus propias reflexiones que serían recogidas en Vers une Architecture (1923), donde alaba, como es sabido, las cualidades de las fábricas americanas y silos con el objetivo de argumentar su doctrina estética exhortando sobre la necesidad de proyectar con las formas esenciales de la geometría platónica concordantes con la clarté de la móŕtqatięlsohn, E. Amerika. Bilderbuch eines Architekten. Berlin, 1926. Mendelsohn conoció al arquitecto y cineasta Fritz Lang en un viaje en barco rumbo a los Estados Unidos en 1924, quien posteriormente estrenaría Metrópolis (1926), también metáfora de la ciudad industrial y de los conflictos suscitados en las relaciones laborales del sistema capitalista.
} 
Industriebaukunst" (El desarrollo de la moderna arquitectura industrial), aparecido en el Jarhbuch des Deutscher Werkbundes en 1913, donde alaba también las primeras realizaciones de edificios industriales modernos como la mítica Fábrica de Turbinas de la firma AEG, obra del arquitecto Peter Behrens, uno de los edificios más divulgados y canónicos en el tránsito a la modernidad. Gropius entre otras cosas introdujo una adjetivación tradicional para calificar la modernidad de estas fábricas y silos, refiriéndose a su monumentalidad comparable a los edificios del Antiguo Egipto por sus características morfológicas de rotundidad, abstracción geométrica, y su carácter autorreferencial y ascético, además de ser edificios que atendían a cumplir los requisitos de su programa. Como es bien sabido, Gropius no había viajado a Estados Unidos, ni conocía estos edificios y fábricas de primera mano, sino a través de "imágenes" fotográficas probablemente suministradas por sus clientes de la fábrica Fagus, lo que prueba ser un buen ejemplo de las múltiples posibilidades que ofrecía la fotografía para elaborar una teoría desvinculada del conocimiento directo de la realidad.

El impacto de estas construcciones americanas en la arquitectura moderna europea fue enorme. La obra futurista de Antonio Sant' Elia en su utópica Città Nuova (1914) aparece poblada de audaces rascacielos, centrales eléctricas, nodos de comunicación de varios niveles urbanos, hangares de aviación, reflejando los anhelos de la utopía tecnológica del momento en un lenguaje puramente maquinista nutrido de las poderosas imágenes de los silos y elevadores del nuevo mundo divulgados en aquellas fechas por Gropius. En el texto que acompaña la propuesta, Sant' Elia planteaba la metáfora de la ciudad como una inmensa máquina tumultuosa y ruidosa acorde con la necesidad futurista de dar expresión a la sociedad de las nuevas tecnologías del momento, como también aborda F. T. Marinetti en el Primer Manifiesto Futurista de 1909 (De Micheli, 1988: 372-73).

Asimismo, las palabras de Sant' Elia describiendo la arquitectura y los elementos de circulación de su ciudad como un perpetuum mobile poseían su correlato real en los mecanismos y en la configuración formal de fábricas, altos hornos o plantas siderúrgicas con escaleras y ascensores que trepaban por las fachadas con sus pasarelas cruzando a varios niveles, ruido y escala. 
Sin embargo, uno de los ensayos más trascendentes en recoger la relevancia que estaba adquiriendo la arquitectura industrial en el desarrollo programático del Movimiento Moderno fue La construcción funcional moderna (1923) del crítico Adolf Behne, quien realiza una reflexión crítica y un compendio sobre las construcciones industriales que se había llevado a cabo previamente en Estados Unidos y en Europa, recogiendo también los primeros ejemplos construidos con el lenguaje del Movimiento Moderno. Como obras maestras de la nueva arquitectura aparecen ilustrados los edificios Industriales de Albert Kahn, Henry Van de Velde, Otto Bartning, Peter Behrens, Walter Gropius,

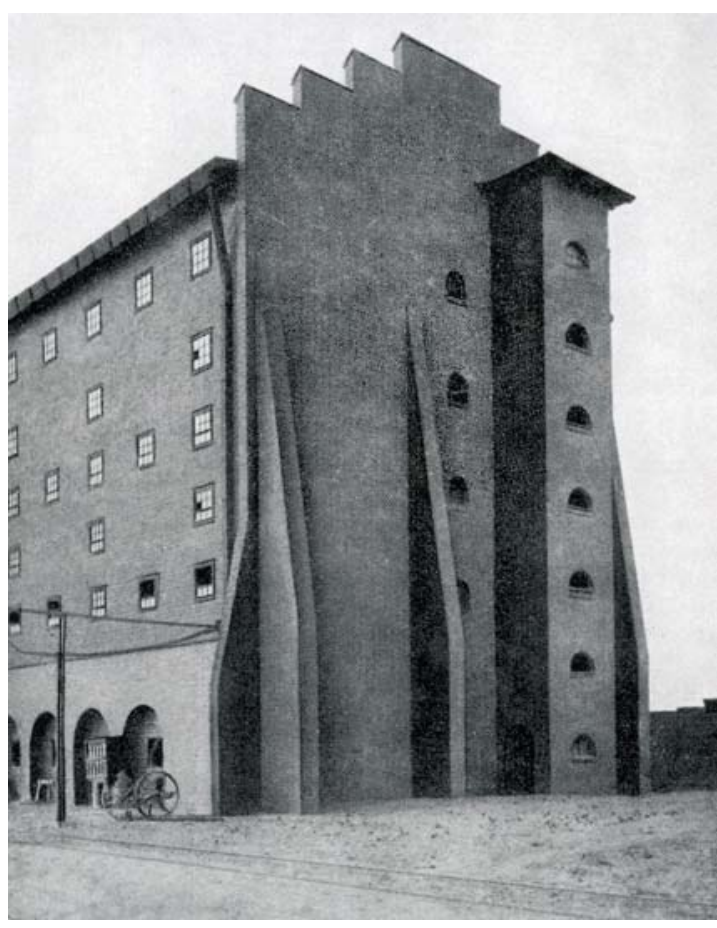

Fig. 5. Hans Poelzig: Fábrica química Luban en Posen (Alemania, 1911-12) Fuente: Adolf Behne: La construcción funcional moderna, p. 102 Hans Meyer, Hugo Haring, Erich Mendelsohn, Hans Poelzig, entre otros, demostrando la pluralidad lingüística que adoptaban las fábricas europeas sin detrimento de su funcionalidad (Fig. 5).

El texto de Behne incide en la influencia de las teorías de Henry Ford no sólo en el diseño arquitectónico de las fábricas modélicas americanas sino también en la moderna arquitectura europea con lemas tan conocidos como Donde no hay limpieza, no hay moral. Disculpamos tan poco la negligencia en la conservación de la limpieza como la negligencia en la producción (Behne, 1994: 38).

La prefabricación en la construcción como ahorro de tiempo de ejecución y costes era aplicada con absoluta rectitud a muchas fábricas desde las primeras décadas del siglo XX, así como la higiene en los espacios del trabajo a través de mejoras en la ventilación, en la iluminación natural, junto a la flexibilidad y la posibilidad de crecimiento, todos ellos principios de la nueva arquitectura moderna. Las ideas de Henry Ford se materializaron, entre otras, 658 
tectura moderna. Las ideas de Henry Ford se materializaron, entre otras, en las fábricas de la Ford Motor Company que la firma construyó en Highland Park, Detroit, obra de Albert Kahn, pionero en la construcción de fábricas flexibles de pisos en hormigón armado e iluminación natural abundante.

Pero además, inscribiéndose en las posturas filantrópicas que habían caracterizado la labor de los grandes nombres de la industria desde el arranque de la Revolución Industrial, y, por otro lado, en un intento de promocionar su propia imagen de industrial con preocupaciones culturales, Henry Ford fue el promotor de la creación de Greenfield Village (Detroit, 1922-1929) un museo al aire libre con fines pedagógicos y de ocio cultural, en forma de escenario de la vida tradicional americana, que, como señala Edward Kaufman, poseía una deuda notable con respecto a las grandes ferias en su función de transmisión de los valores de una ideología diferencial americana. Greenfield Village era un lugar creado artificialmente mediante el traslado de edificios y objetos de otros lugares cuyo fin era ofrecer una imagen idílica del medio rural (Kaufman, 2004: 283-284), con sus modos de vida pre-industriales, explotaciones agrarias, rebaños y manufacturas artesanales, en una suerte de espacio de la arqueología industrial que debía reflejar también la idea del progreso de la técnica y la industria mediante la obra del propio fundador. espacio de las fábricas en función de los procesos y ciclos productivos, en su filosofía industrial existe una explícita recomendación de evitar el monumentalismo en el diseño de las fábricas, ideas que fueron recogidas en el texto de Moritz Kahn The Design and Construction of Industrial Building (1917) (García Braña, 2005: 38). Si las ideas de Ford tuvieron una gran repercusión en Europa, incluida la Unión Soviética, sin embargo, en Europa, el fordismo se inscribirá en tendencias culturalistas que serán las responsables de que en el primer tercio del siglo XX aparezca en países como Alemania una arquitectura industrial participante en la esfera de la kultur alemana, nutrida de consideraciones filosóficas y simbólicas, además de adoptar los avances técnicos en la construcción, la energía eléctrica y la introducción de nuevos procesos de producción. Contradiciendo las ideas de Ford, las fábricas europeas iban a revestirse de una plusvalía estética que las elevaría a la condición de hitos de la historia de la arquitectura de la modernidad, especialmente en Alemania, en que la influencia ideológica de Herman Muthesius fomentó la vinculación de arquitectos a potentes firmas Arte y Ciudad - Revista de Investigación 2013 (Junio) $n^{\circ} 3$ (I) Extraordinario 
de arquitectos a potentes firmas empresariales. Los empresarios expresarán su prestigio a través de edificios funcionales con la plusvalía de un buen diseño arquitectónico y el arquitecto cobrará cada vez más protagonismo en el diseño de fábricas y edificios industriales.

El programa del Deutscher Werkbund así lo atestigua en su anhelo de dignificación del diseño industrial, a lo que contribuirán arquitectos como Behrens y el propio Gropius, el primero contratado por la empresa Allgemeine Elektrizitäts-Gesellschaft (AEG, Sociedad General de Electricidad) en 1907 para el diseño de todos sus productos, destacó en la construcción de la imagen de marca de la empresa con un hito arquitectónico, la monumental fábrica de turbinas que aúna magníficamente el aura cultural del clasicismo como máscara ennoblecedora con el funcionalismo técnico de su espacio interior productivo ${ }^{10}$. La fábrica Fagus en Alfeld an der Leine construida por Walter Gropius y Adolf Meyer (1911-1914), fue uno de los edificios modernos más divulgados en las publicaciones de la época mediante una sabia potenciación fotográfica de su cualidades más innovadoras como el incipiente uso del muro cortina o la esquina acristalada, hasta el punto de recrear efectos que en realidad eran falsos desde el punto de vista constructivo.

Este cambio de sensibilidad hacia el diseño y la estética de la moderna arquitectura industrial fue divulgado en España por el arquitecto Teodoro de Anasagasti en un artículo publicado en 1915 en La Construcción Moderna con el título "El arte en las construcciones industriales", en el que presentaba los ejemplos de arquitectura industrial moderna que se habían construido en Alemania por parte de arquitectos como el propio Peter Behrens en la fábrica AEG de Berlín y en los gasógenos de Frankfurt. Anasagasti, que utilizó las cuestiones más formales del debate, entendía con espíritu crítico que la presencia en la ciudad de los complejos fabriles determinaba esa necesidad de atribuirles un "carácter", al tiempo que contraponía la situación alemana a los prejuicios existentes en el contexto de la cultura arquitectónica española, sumida aún en los historicismos académicos, reacia a la asimilación de la

\footnotetext{
${ }^{10}$ Todo ello revela la madurez que estaba adquiriendo la temática industrial como tema proyectual en Europa, así como el juicio crítico de Behne hacia la arquitectura industrial de Behrens (Bhene, 1994: 41-42-43-44).
} 
belleza del maquinismo y de la construcción moderna funcional, resucitando de este modo un viejo debate entre arte y técnica, tradición y progreso como términos discordantes, que también tendría su correlato en los edificios construidos por entonces ${ }^{11}$.

Paralelamente en Europa se interpretaban las ideas fordistas en un ejemplo paradigmático, la fábrica Fiat Lingotto en Turín, proyectada en 1915 por el ingeniero de la empresa, Giacomo Mattè Trucco ${ }^{12}$. La impactante fábrica, publicada ampliamente por las revistas internacionales de la época y por el propio Le Corbusier en Vers une Architecture recreando la fotogenia de las vistas aéreas que captaban su cubierta con la audaz pista de pruebas de un kilómetro de longitud como punto final de la cadena de montaje, ejemplificaba también gracias a la fotografía aérea la imagen prototípica de la modernidad tal como la habían enunciado en propio suelo italiano los artistas y arquitectos del Futurismo, subordinando claramente la funcionalidad americana a la plusvalía estética europea.

\section{La imagen y los efectos de la desindustrialización.}

Las fábricas modernas ocuparán también solares periféricos, áreas de concentración tradicional de la industria o nuevas áreas de desarrollo próximas en los bordes urbanos, si bien, frente a la nítida zonificación y racionalización propuesta por los teóricos del urbanismo de la ciudad industrial, en la práctica, en muchas ocasiones, la implantación fue desordenada y caótica, dando lugar a problemas de toda índole.

La crisis y la consiguiente reconversión industrial fruto de los cambios conceptuales y estructurales en la economía global así como de los cambios tecnológicos en los sistemas productivos afectó, fundamentalmente desde la

\footnotetext{
${ }^{11}$ Anasagasti, T. de, “El arte en las construcciones industriales", La Construcción Moderna, Madrid, 15 de junio de 1915, no 11, año XIII, pp. 166-169.

${ }^{12}$ Giovanni Agnelli había conocido a Henry Ford en Detroit y había sido seducido por su doctrina de los sistemas de la cadena de montaje móviles y de la estandarización de los elementos, además las fábricas de Highland Park fueron publicadas en la revista italiana L'Industria en 1915 y 1916.
} 
década de los años sesenta y los setenta del siglo pasado, al sector económico de gran parte del mundo industrializado occidental, provocando un cierre paulatino y masivo de complejos y fábricas adscritos a sectores como la minería, la siderúrgica, la industria naval o las químicas. Los impactos urbanísticos, socio-económicos y medioambientales de la desindustrialización fueron nefastos y generaron también un paisaje propio de la industria obsoleta, donde afloran los restos arruinados de las edificaciones, infraestructuras de transporte e instalaciones (Benito, 1993, 2012), entre los cuales se descubren bienes patrimoniales de indudable valor arquitectónico, técnico, histórico y urbano-territorial.

Además de las lamentables consecuencias humanas, hay que destacar los impactos a nivel visual, urbano y territorial. La asociación de periferia degradada e industria se ha convertido en un lugar común, el cese de la actividad generando amplias franjas periurbanas con una problemática de marginación, tensiones sociales, actos de vandalismo, peligro de derrumbe, derribos intencionados de partes de la edificación, especulación con el suelo recalificado, constituyen una casuística reiterada. El caso de Detroit es paradigmático de la obsolescencia industrial de larga duración generadora de una problemática urbana aún pendiente de solución. El proceso evolutivo de decadencia de la industria automovilística desde mediados del siglo XX ha convertido a la ciudad emblemática del fordismo y las fábricas modélicas de hormigón en un escenario desolado producto del impacto de la desindustrialización en el tejido urbano (Fig. 6). 


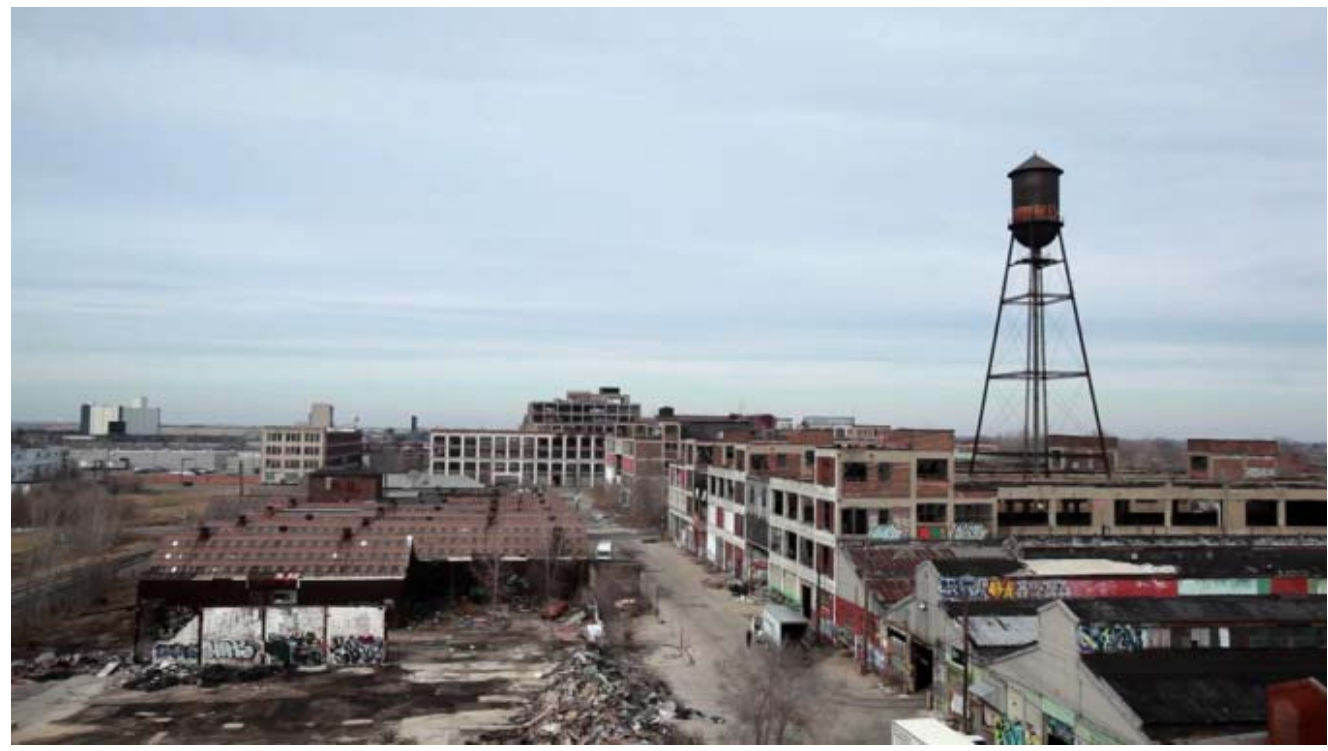

Figura 6: Vista de las ruinas de la fábrica Packard Motor de Detroit diseñada por Albert Kahn (Extraída del video documental HILL (This Must Be the Place) dirigido y producido por Ben Wu y Daniel Usui Fuente: Revista METALOCUS. 11/04/2012. http://www.metalocus.es/content/es/blog/hillv\%C3\%ADdeo-o-la-fabrica-packard-motor-car-dise\%C3\%B1ada-por-albert-kahn.

La principal causa del problema fue la reubicación de la industria en el área metropolitana, la construcción de una red ilógica de autopistas y la posterior competencia de la industria automovilística japonesa (Fernández Águeda, 2009). La consecuencia del cierre de las fábricas provocó desempleo, descenso poblacional, y el derribo de áreas antiguas residenciales e industriales. La imagen del nuevo paisaje urbano está asociada al declive y la ruina, como condición de imposibilidad de adaptación a las nuevas realidades, o como imposibilidad de salir de la crisis, lo que plantea el riesgo de la fosilización de este escenario cuya imagen decadente se ha convertido en un escenario atractivo para creadores como el reconocido sociólogo y fotógrafo Camilo José Vergara dedicado desde los años ochenta a la captación de slums y ámbitos urbanos degradados, y célebre por su propuesta de conversión Detroit en una Acrópolis Americana de la ruina industrial, asimilable a las ruinas de las antiguas civilizaciones muertas, con un único

destino la fruición cultural. ha sido un tema frecuente desde el último cuarto del siglo $\mathrm{XX}$ y se ha materializado en las conocidas acciones llevadas a cabo por parte de artistas, 
lizado en las conocidas acciones llevadas a cabo por parte de artistas, galeristas, coreógrafos, fotógrafos, cineastas, sobre edificios y paisajes industriales, entre la apropiación estética y la ocupación física de los edificios. La imagen marginal y la poética de la ruina asociada al paisaje y los bienes obsoletos de la industria recobran su poder catalizador para la creación artística como signo de transgresión y de desmitificación de la obra como mercancía materialmente valiosa frente a la cultura institucional (Fig. 7).

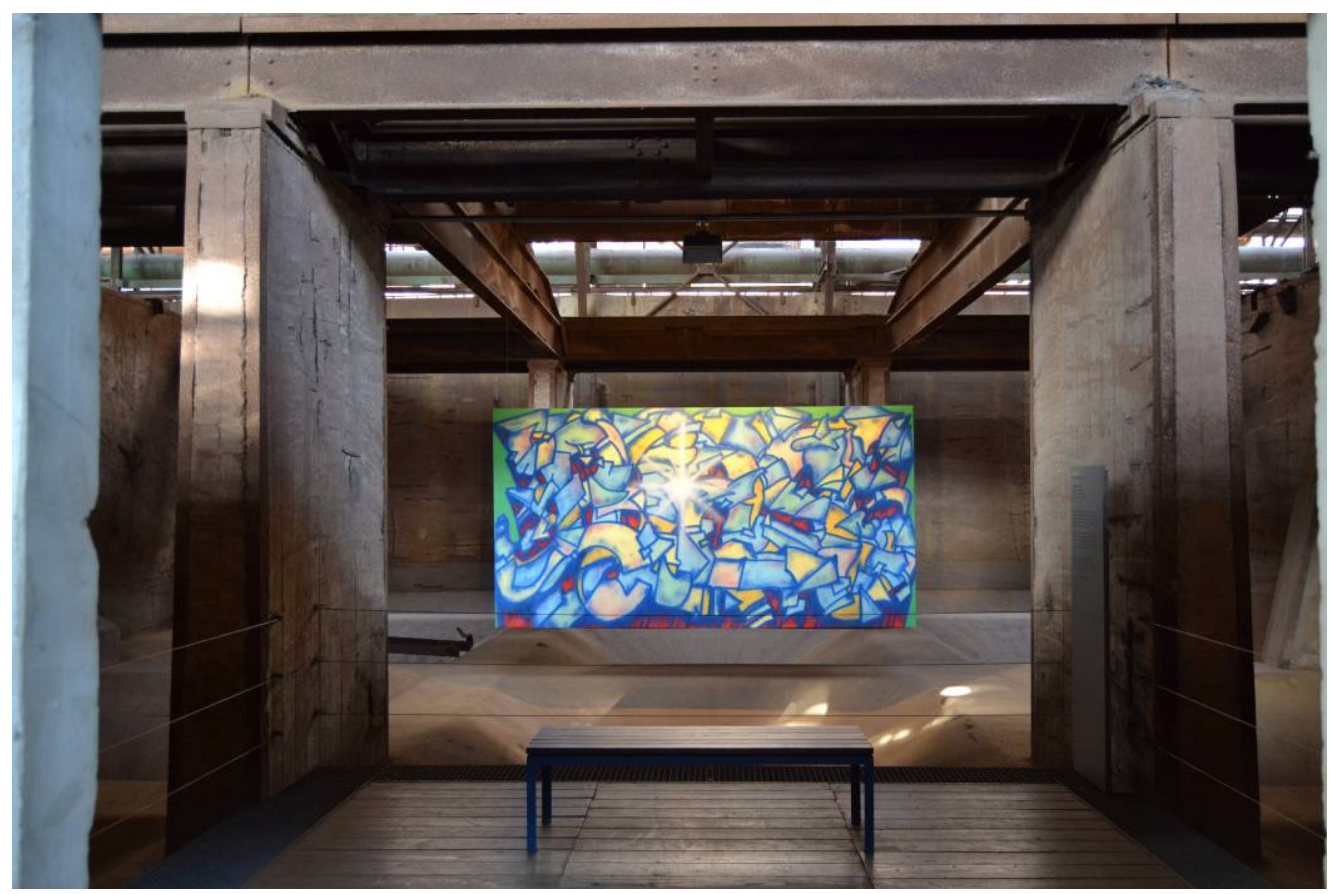

Fig. 7 Acería de Völklingen (Saarbrücken, Sarre, Alemania). Bienal Urban Art Graffiti 21, Phase2. Marzo - Noviembre de 2013. Foto A. Layuno.

En la década de los sesenta se estaban estableciendo en paralelo las bases para la conservación patrimonial de los bienes de la industria. La fotografía fue también en la segunda mitad del siglo un medio idóneo que contribuyó a "hacer ver" y tomar conciencia de la nueva realidad sensibilizando hacia la valoración estética y patrimonial industrial. En Alemania destacan los trabajos de Bernd y Hilla Becher, quienes comenzaron a trabajar en 1959 fotografiando instalaciones y construcciones industriales en sus viajes por Europa y Estados Unidos. 
Si las fotografías de Gropius habían contribuido a la formación de una nueva imagen de la génesis de la modernidad idealizando meras construcciones anónimas de la industria, ahora se reproduce el proceso de estetización de las instalaciones industriales con fines documentales, artísticos e implícitamente de conservación patrimonial. Los Becher empezaron a fotografiar los paisajes y edificios de la Cuenca del Ruhr, interesándose por el diseño de silos, torres de agua, fábricas, naves, castilletes de extracción, altos hornos, fundiciones, gasómetros, torres de refrigeración, depósitos de agua, vivienda obrera, entre otros, valorando dos aspectos básicos de los mismos: su valor plástico ${ }^{13}$, y su valor tipológico. En relación al primero, externalizando el interés de "edificios-máquina" como los castilletes de extracción o los gasómetros, cuyas formas les fascinaban por sus valores plásticos independientemente de su funcionalidad, tal como hicieron algunos arquitectos de vanguardia (Fig. 8). El segundo aspecto enfatiza la idea de tipificación o seriación, y parece poseer un carácter estético, analítico y descriptivo expresado mediante el procedimiento comparativo de series que revelan semejanzas y diferencias de construcciones del mismo tipo procedentes de varios lugares de Europa, con funciones idénticas pero que pueden variar en aspecto y pro materiales (Zuipeite 2005 ) vista único, rígidamente frontal, el uso del blanco y negro y una luz homogénea sin sombras es sólo objetivo en apariencia pues las construcciones aparecen en una suerte de a-contextualización abstracta, que las desvincula de toda contingencia histórica -espacial y temporal-, por ello, a pesar de la reivindicación de la idea de contexto y de lugar que se desarrolla en los años en que se realizan estos álbumes, el aislamiento y la soledad en que aparecen los objetos en sus imágenes fotográficas anticipan los resultados obtenidos en muchas operaciones de recuperación patrimonial de estos bienes, una vez eliminados los elementos secundarios que les conferían un significado. En su análisis de los antecedentes y rasgos de la obra de los Becher, Armin Zweite afirma que los Becher han redescubierto unos estilos muy difundidos en los años veinte, sobre todo en torno a un nuevo realismo y la estética de la

${ }^{13}$ El álbum “Anonyme Skultpuren. Eine Typologie industrieller Bauten” (Esculturas Anónimas. Una tipología de las construcciones industriales), fue publicado en 1970 en Düsseldorf. 
máquinas de aquel momento, señalando una cercanía a Albert Renger-Patzsch, autor del libro El mundo es bello (1928), quien planteó el rechazo de la denominada fotografía "artística" a favor de ese carácter objetivo y del mundo de los objetos.
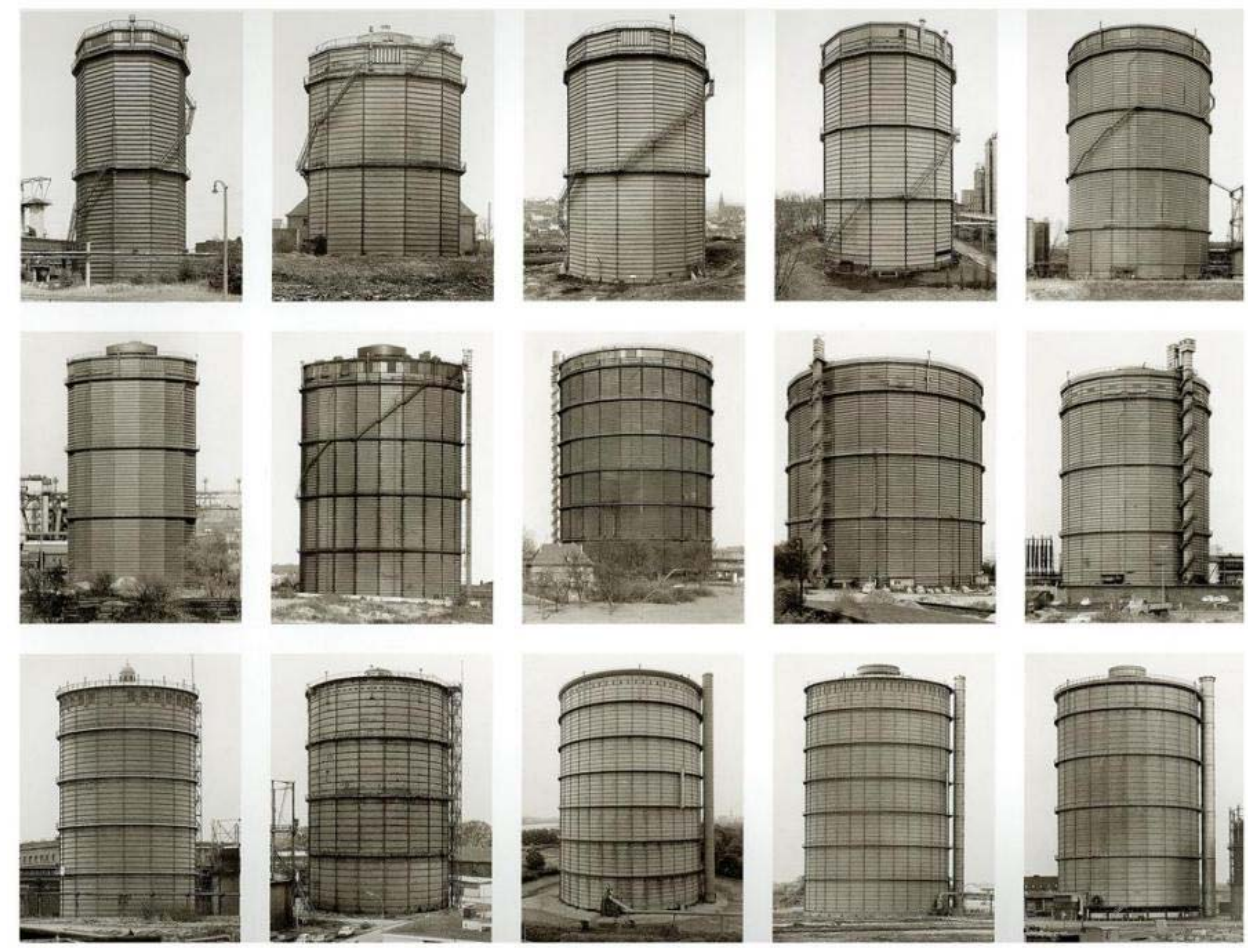

Figura 8: Bernd y Hilla Becher: Gasbehälter (Gasómetros). Los ejemplos proceden de diversos lugares industriales de Alemania, fotografiados entre 1976 y 2001 (Fuente: Zweite, 2005)

En relación a una implícita sensibilidad patrimonial de sus fotografías, los Becher estaban registrando la memoria de unos objetos "efímeros" que estaban siendo demolidos debido a la crisis y reconversión industrial que afectó al carbón y al acero en el centro de Europa desde finales de los años cincuenta, provocando la decadencia económica de grandes regiones con 
consecuencias sociales conocidas ${ }^{14}$. Las fotografías de los Becher se inscriben de esta forma en el contexto de la lucha por la preservación de los monumentos industriales en Alemania y en otros lugares de Europa, materializados en el caso alemán por las primeras declaraciones de monumento, medidas de conservación y restauración de los bienes industriales, superando los criterios de valoración monumentales y de carácter artístico para abordar cuestiones por ejemplo de índole tecnológica o tipológica como se observa en sus series de objetos.

Pese a la rigidez de sus enfoques, la fotografía era para los Becher el medio más adecuado para registrar la naturaleza dinámica del paisaje industrial, para "monumentalizar" las instalaciones, documentándolas como medida de preservación de su memoria y de su existencia ante la inminente destrucción definitiva. Su trabajo sobre el patrimonio industrial actúa de este modo de mediación de la visión (Moya, 2011: 84-85), y contribuye a despertar una nueva sensibilidad por la belleza romántica de las ruinas de los paisajes industriales como construcción cultural de la contemporaneidad, idea compartida con las fotografías citadas de Camilo José Vergara en Detroit.

\section{Refuncionalización.}

En la década de los sesenta del siglo XX surge en Inglaterra la Arqueología Industrial como disciplina encargada de documentar, inventariar, proteger conservar y restaurar los restos materiales del pasado industrial, como consecuencia de la amenaza y pérdida de un patrimonio que adquiere una posición central en la definición de su historia nacional. En Inglaterra cimentaron la creación de una nueva disciplina los trabajos de Keneth

\footnotetext{
14 Aunque no estaban implicados directamente en el campo de la conservación de los monumentos, aportan disecciones técnicas de series tipológicas como castilletes de extracción o torres de agua, además, algunas de sus fotografías ilustraron sendos estudios de tipo histórico financiados por la Fundación Fritz Thyssen: Die Architektur der Förder-und Wassertürne (1971) y el álbum "Zeche Zollern 2. Ausbruch zur modernen Industriearchitektur un Technik. Entstehung und Bedeutung einer Musteralage in Dortmund um die Jahrhundertwende (1973). En este caso, se documenta de manera exhaustiva un complejo industrial afectado por el cierre, con todos sus detalles internos y externos (Zweite, 2005: 11, 27-28).
} 
Hudson y Augus Buchanan. Hudson fue autor de los primeros textos Industrial Archaeology. An introduction en 1963, al que seguiría Industrial Archaeology of South England (1965), y la edición en 1964 del Journal of Industrial Archaeology. En Inglaterra la labor de investigación y difusión fue respaldada por los estudios de críticos y teóricos del Movimiento Moderno como J.M. Richards y N. Pevsner, editores de la revista Architectural Review, desde la cual impulsaron los estudios y proyectos de la nueva disciplina ${ }^{15}$.

Estos trabajos sientan las bases de las primeras catalogaciones y actuaciones rehabilitadoras muchas de ellas superadoras del concepto de monumento aislado para conservar e interpretar los vestigios de la industrialización dispersos en la ciudad o el territorio, recreando la vida industrial con recursos didácticos y lúdicos para el disfrute turístico. Es el caso del Ironbridge Gorge Museum (1973), ligado al mítico Coalbrookdale, tal como predecían los grabados y pinturas del siglo XVIII antes mencionados; o New Lanark ${ }^{16}$, que abre un debate sobre los criterios de restauración, conservación y la programación que debía primar en su reconversión cultural.

En las décadas siguientes, en términos generales, la evolución de los conceptos patrimoniales ha generado un amplio movimiento internacional hacia la conservación de los paisajes y del patrimonio industrial. La Convención Europea del Paisaje (Florencia, 2000) ${ }^{17}$, al reconocer la potencialidad del paisaje como recurso económico favorable para las comunidades gestoras, y como elemento de identidad, tanto los espacios de reconocida belleza excepcional como los más cotidianos y degradados, fomenta las operaciones relacionadas con el patrimonio y el paisaje industrial. El Memorandum de Viena (2005) ${ }^{18}$, acuña un nuevo término, el paisaje urbano

${ }^{15}$ De especial interés para el tema es el análisis realizado en la editorial “Industrial Archaeology Today", en Architectural Review, no 832, Junio 1966, pp. 421-424.

${ }^{16}$ Sobre los criterios de recuperación empleados en New Lanark véase Alison, F., “Verifica di una utopia/Verifying a Utopia", en Casabella Continuitá, no 388, 1974, pp. 39-43.

${ }^{17}$ El Convenio Europeo del Paisaje fue ratificado por el estado español en 26 de noviembre de 2007 y entró en vigor el 1 marzo de 2008.

${ }^{18}$ Resultado de la Conferencia Internacional sobre el tema "Patrimonio Mundial y Arquitectura Contemporánea. Gestionando el Paisaje urbano histórico", patrocinada por la UNESCO y celebrada en Viena entre 12 y el 14 de mayo de 2005. 
histórico, superando la idea de edificio para considerar el lugar, el perfil de la ciudad, los ejes visuales, las líneas y tipos de edificios,... las infraestructuras..., como reflejo de los cambios de uso del suelo producto de los contextos económicos (Rivera, 2011: 137-139), lo que abriría a su vez la posibilidad de incluir los paisajes urbanos de la industria como una categoría válida en la clasificación que hace la UNESCO de los paisajes culturales ${ }^{19}$. Iniciados los debates conceptuales sobre el tema con los estudios pioneros de Franco Borsi, Georges van Abeleen o Cliff Tandy ${ }^{20}$, han sido numerosos los textos y los documentos internacionales, nacionales y regionales que apuestan por la investigación y la recuperación de estos paisajes, desde la Carta de Nizhny Tagil (TICCIH, 2003) ${ }^{21}$, al Plan Nacional de Patrimonio Industrial español (2000, 2011), que define los paisajes industriales como aquellos en los que se conservan visibles, todos los componentes esenciales de los procesos de producción de una o varias actividades industriales, incluidas, las transformaciones del paisaje ocasionadas por dichas actividades22.

No obstante, este marco patrimonial se entrecruza con otras realidades que afectan a los solares y áreas de la industria obsoleta. La post-industrialización desarrolló un cambio de paradigma ideológico y la transición hacia una sociedad de consumo, imagen y plusvalías culturales aparejada a fuertes

\footnotetext{
${ }^{19}$ Véase la página de la UNESCO: http://whc.unesco.org/en/culturallandscape/

${ }^{20}$ Los pioneros en aplicar y definir el término "paisaje de la industria" fueron Franco Borsi, Le paysage de l'industrie. Région du Nord. Bruxelles: Edtions des Archives d'Architecture Moderne/Éditions du Moniteur, 1975; el belga Georges Van den Abeelen, L'archeologie industrielle. De $l$ 'aventure à la science. Bruxelles: Racine, 1997. Y la célebre obra de Cliff Tandy Industria y Paisaje, desde el punto de vista de los impactos de la industria en el paisaje citada en las referencias de este artículo. El planteamiento de estos autores se filtra posteriormente en los documentos normativos internacionales.

${ }^{21}$ El TICCIH es la organización mundial encargada de la preservación y tutela del patrimonio industrial y es asesor especial de ICOMOS en cuestiones de patrimonio industrial. El texto de la carta fue aprobado por los delegados reunidos en la Asamblea Nacional del TICCIH, de carácter trienal, que tuvo lugar en Moscú el 17 de julio de 2003. El contenido del documento se halla en el enlace: http://international.icomos.org/18thapril/2006/nizhny-tagil-charter-sp.pdf ${ }_{22}^{2}$ Plan Nacional de Patrimonio Industrial, en Bienes Culturales. (Revista del IPHE), 7, 2007. Véase el documento en www.mcu.es/patrimonio/docs/MC/.../PN_PATRIMONIO_INDUSTRIAL_pdf (texto revisado y ampliado en marzo de 2011).
} 
mutaciones en el paisaje urbano de las áreas industriales, las cuales se convertirán en áreas de oportunidad para nuevos desarrollos, siendo objeto de planes y proyectos de ordenación y regeneración urbana para usos terciarios y residenciales previa recalificación del suelo industrial (Pardo Abad, 2004: 13-14). El objetivo prioritario es la búsqueda de la "limpieza" ambiental, de lo ecológicamente sostenible y de un progreso cuantificable en parámetros culturales y ambientales, en operaciones cuya finalidad es solucionar la problemática generada apostando por una recuperación funcional, y en otros casos, por la eliminación total para emplazar otros usos (Benito del Pozo, 1993). El caso español de la Ría de Bilbao ha sido paradigmático en este sentido (García Merino, 1982). Ante ello, se plantea la necesidad de investigar acerca de la interrelación entre fenómenos de desindustrialización, políticas urbanísticas y políticas de protección patrimonial de los bienes y paisajes urbanos de la industria, conscientes de las constantes interferencias que existen entre estos ámbitos.

La recuperación de la Cuenca del Ruhr como la región industrial más extensa de Alemania ha estado presidida por una serie de planes y proyectos ejecutados en varias fases a través de la IBA Emscher Park (1989-1999) seguida del Plan Director sobre el paisaje industrial del río Emscher (20012006), enlazando con la concesión de la capitalidad europea para la región en 2010. El marco en que se desarrollaron los proyectos y las características de la propia región fueron determinantes en la vocación eminentemente ecológica, turístico-cultural y terciaria de muchas de las actuaciones (Fachgebiet Städtebau, 2008). En concreto la celebración de la capitalidad europea fue determinante en la adopción de programas y métodos de intervención en los edificios industriales apostando fuertemente por la cultura y el ocio, transformando radicalmente la imagen de la contaminación y la dureza del trabajo en actividades acordes con la sociedad del tiempo libre y el disfrute cultural a través del turismo.

Es esta quizás la imagen que más ha trascendido del reuso de los imponentes complejos industriales y que puede haber suscitado la crítica hacia la denominada espectacularización de las ruinas industriales y también hacia el mantenimiento de su viabilidad en una Europa en crisis. Sin embargo, la realidad es más compleja en un análisis más profundo. La recuperación de la zona se concibió dentro de un programa de política 
estructural en el marco de la reconversión industrial del estado de Nordrhein-Westfalen, zona puntera en la industria del carbón y el acero, muy afectada por las consecuencias de la crisis y con ruinas de gran escala. Los proyectos llevados a cabo en las décadas citadas poseen como objetivos básicos la regeneración ecológica y urbana como tema central ligada a un programa de recuperación de los monumentos industriales por medio de la Fundación para la Preservación de los Monumentos Industriales que proporcionó un marco legal y de gestión evitando demoliciones y fomentando declaraciones de algunos bienes como Patrimonio de la Humanidad, como es el caso de la mina Zollverein (Figs. 9-10).

El concepto de paisaje como entidad en evolución constante preside las actuaciones, que se re-escriben a modo de palimpsesto en torno a la espina dorsal del río Emscher, impulsando escalas y figuras de actuación variables, desde la red de senderos ciclistas y la creación de una tupida área verde regional, a la recuperación selectiva del patrimonio industrial, a la creación de rutas o itinerarios culturales de la industria dentro de la red ERIH ${ }^{23}$. La difusión del nuevo escenario del Ruhr se ha teñido de un discurso en torno a la calidad ambiental y a la percepción de un nuevo paisaje cultural urbano. El objetivo prioritario ha sido la búsqueda de la "limpieza" ambiental, de lo ecológicamente sostenible y de un progreso cuantificable en parámetros culturales y ambientales, sin borrar las huellas de la memoria de la industria. En este proceso se han ofrecido modelos metodológicos de intervención y gestión del patrimonio industrial dignos de consideración y de valoración a partir de la reflexión sobre las condiciones económicas, sociales y culturales que los han generado.

\footnotetext{
${ }^{23}$ Parte de los hitos patrimoniales de este espacio regional se inscriben en la ERIH (European Route of Industrial Heritage) cuyos objetivos fueron la construcción de una red turística especializada en los bienes del pasado industrial, promover el papel de la historia industrial en la contribución a la identidad local, ayudando a los ciudades a tomar conciencia de esta fase histórica. La ERIH se construye sobre un sistema de anchor points o hitos de anclaje que son escalas en la ruta: fábricas de acero, minas, gasómetros, destacando la fábrica siderúrgica de Völklingen en la región del Sarre, patrimonio cultural de la Humanidad de la UNESCO y el Complejo de la mina de Zollverein, también patrimonio de la Humanidad.
} 

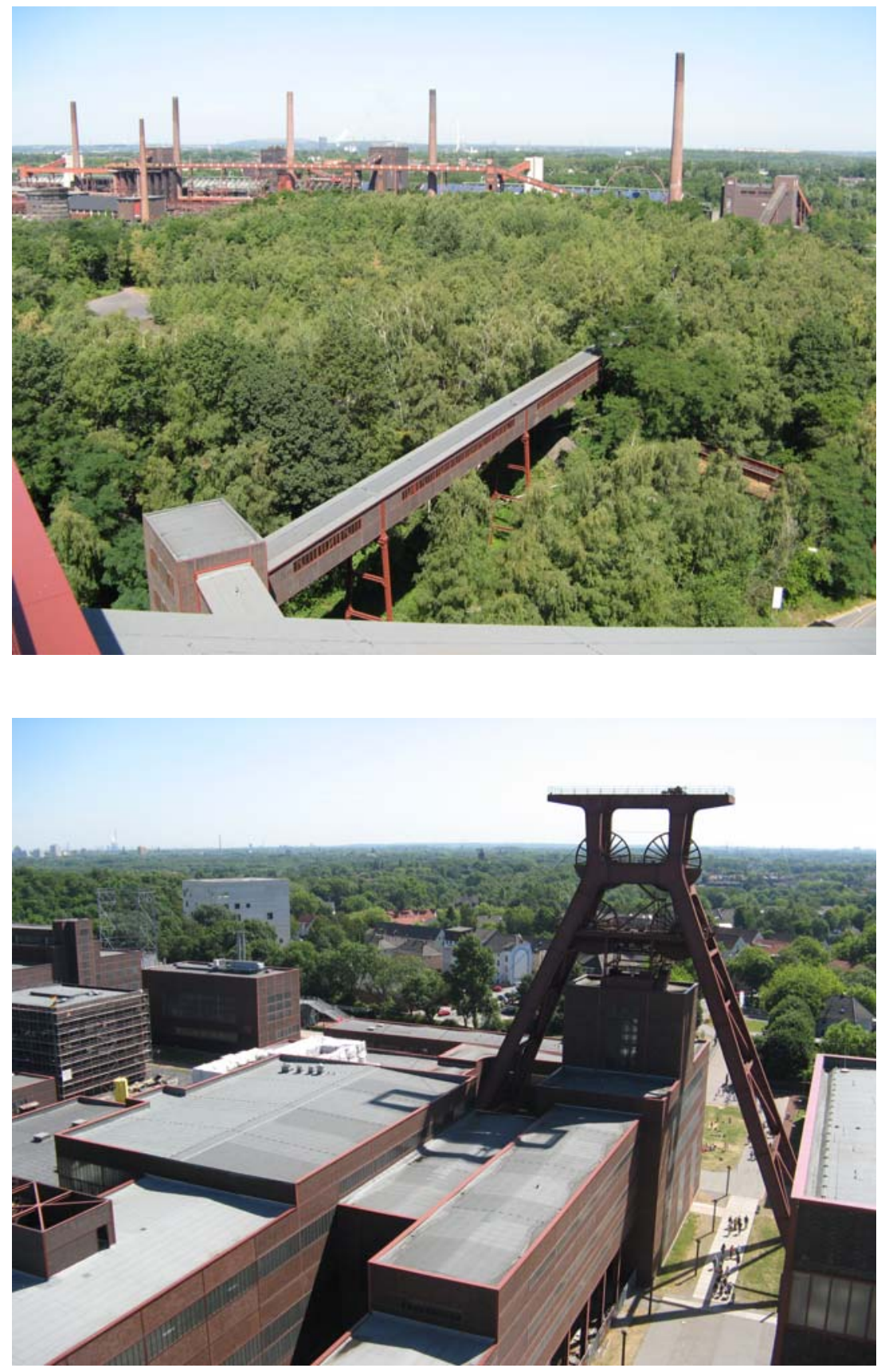

Figuras 9 - 10: Zollverein (Essen, Alemania). Vista de conjunto con la planta de fundición de carbón al fondo, y vista del castillete del Pozo XII declarado Patrimonio de la Humanidad (Foto: A. Layuno). 
El último ejemplo ofrece una actuación de naturaleza opuesta en su formalización, naturaleza y gestión pero con algunos planteamientos de fondo comunes. El proyecto del MAM, Museo a cielo aperto dell'architettura moderna (2001) implica la musealización e interpretación del patrimonio urbano y arquitectónico de Ivrea (Piamonte, Italia), sede de la firma Olivetti, cuyo desarrollo más notable se produjo entre la década de los años treinta y sesenta del siglo pasado. El proyecto museístico es un propuesta original de recuperación de los edificios del Movimiento Moderno adscritos a la empresa y también de la memoria y la morfología urbana marcada por la industria, lo cual ha provocado la redacción de un marco legislativo de salvaguarda y restauración de los edificios afectados en el recorrido museográfico (Figs. 1112).

Lo interesante y novedoso reside en este caso en la interpretación de la ciudad de la industria sobre un soporte físico activo y diversificado en sus funciones, constituyendo el museo un ejemplo de puesta en valor de los bienes arquitectónicos de una extensa área de la ciudad compatible con el mantenimiento de la vida cotidiana. Para ello, una superestructura interpretativa itinerante cruza gran parte del trazado histórico jalonando los puntos de interés mediante estaciones que contienen paneles explicativos sobre los diversos edificios, construidos por destacados arquitectos italianos del Movimiento Moderno ${ }^{24}$, y también sobre la figura del fundador, Adriano Olivetti y su programa, social, político y cultural destinado a la comunidad industrial (Bonifacio, 1999: 191-197) ${ }^{25}$.

\footnotetext{
${ }^{24}$ Como Ignazio Gardella, L. Figini y G. Pollini Mario Ridolfi, L. Quaroni, Luigi Piccinato. Las antiguas oficinas, centro social, comedores, funcionan actualmente como facultades, centros sociales, oficinas, así como los distintos bloques de viviendas construidas para técnicos y trabajadores de la empresa.

${ }^{25}$ Adriano Olivetti escribió un texto que contenía sus ideas comunitarias L'ordine politico della comunità, a partir del cual se construyó el Movimiento de la Comunidad, al que se aproximaron muchos intelectuales. En los años cincuenta tras haber impulsado diversos planes de urbanismo en Ivrea y zonas limítrofes fue nombrado director del Instituto Nacional de Urbanismo. Fue director de revistas de urbanismo como Metron, Comunità, Urbanistica, entre otras labores editoriales y de difusión.
} 

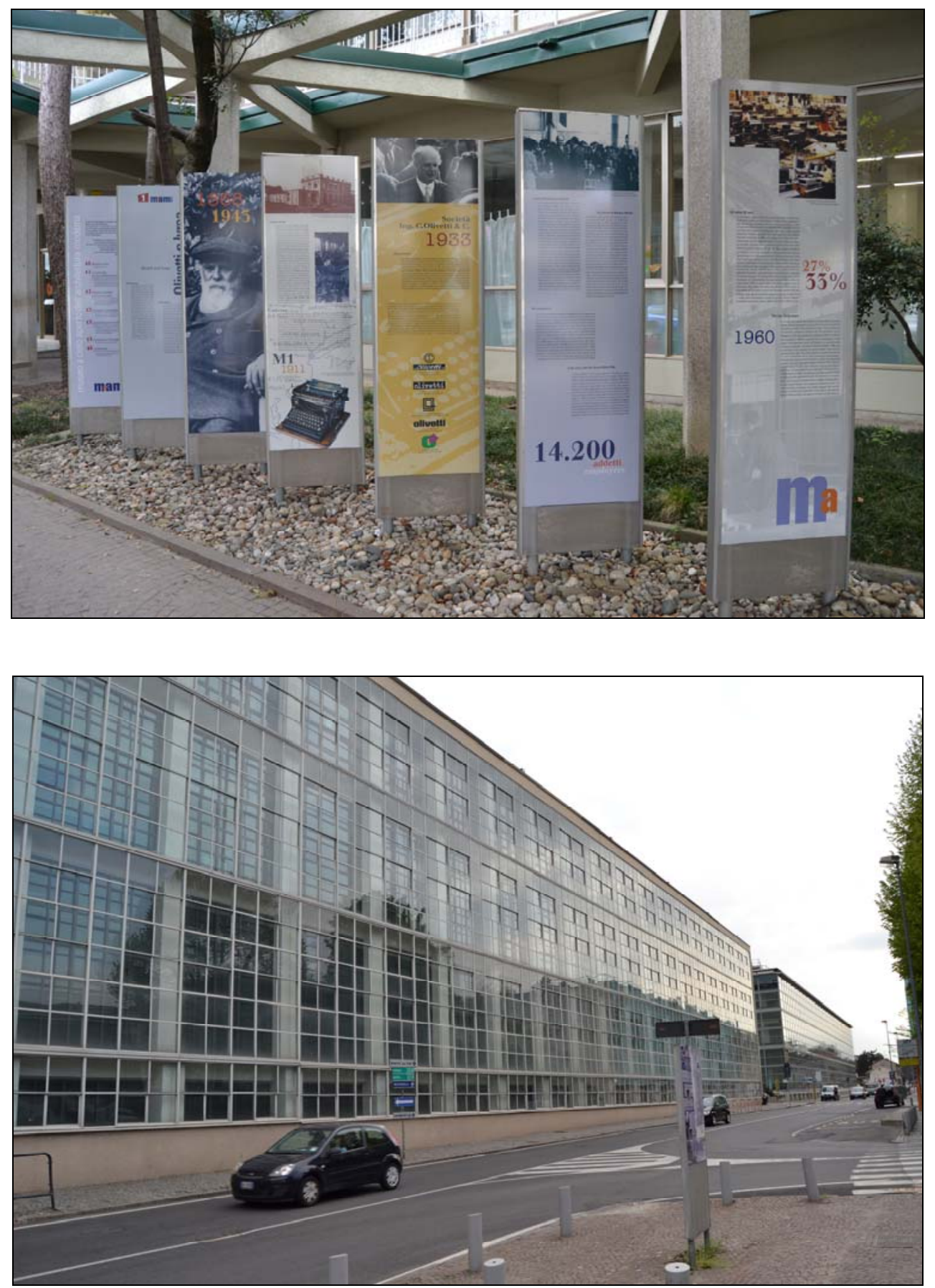

Figura 10: Museo al aire libre de la arquitectura moderna. Ivrea, Italia (Fotos: A. Layuno) 
Atendiendo a la práctica de la conservación de los bienes culturales in situ, en Ivrea se aplica un método de museografía urbana (Minissi, Ranellucci, 1992) en el sentido de concebir la ciudad "como museo de la memoria histórica" susceptible de coexistir con la vida cotidiana y con las actividades funcionales, apartándose en este sentido de situaciones ficticias y aspirando a que las estrategias museográficas aplicadas al tejido urbano funcionen positivamente en la revitalización socio-económica y cultural del lugar, manteniendo la autenticidad del patrimonio moderno y evitando los derribos y planes de recalificación.

\section{Conclusiones.}

El empeño por esclarecer la esencia diacrónica del paisaje industrial acompaña estas reflexiones vinculadas a la historiografía de la arquitectura y el patrimonio, así como a la historia de la ciudad, lo que lógicamente podría ramificarse en otros tantos discursos paralelos o alternativos desde disciplinas como la geografía, la historia social y económica, la ordenación territorial, o la ecología.

Las interrelaciones entre industria y procesos culturales planteadas sintéticamente en estas páginas permiten, por un lado, realizar un recorrido temporal por la apreciación mudable que la sociedad de cada época obtuvo de los impactos que las actividades económicas ejercieron en la ciudad y en el paisaje. Por otra parte, la mala conciencia forjada hacia los impactos que causaban las actividades productivas está en el origen de muchas de las posturas filantrópicas y de mecenazgo desarrolladas en los siglos XIX y XX. Humphry Repton, buscando atenuar el enfrentamiento entre naturaleza y técnica como un arquetipo heredado del origen de la industrialización, plantea la integración armónica de la industria en el paisaje de sus láminas.

En segundo lugar, podemos afirmar que las acciones artísticas en todas sus manifestaciones ha jugado siempre un papel crucial en el hecho de "hacer ver", señalar y visualizar la realidad de la técnica y la industria en todas sus fases, conformando también un imaginario colectivo en torno a la industria que ha forjado la sensibilidad contemporánea, como es el caso del cine de Ruttmann, los trabajos fotográficos de los Becher o de Camilo José Vergara, desembocando en una santificación de los restos y en la activación de 
medidas de conservación de los bienes y paisajes. Muchas veces con el transcurso del tiempo y el cese de la actividad de la industria, el único patrimonio conservado son los archivos visuales, fotográficos y cinematográficos, los cuales, junto a otras fuentes documentales constituyen un corpus que debería ocupar una atención especial por parte de los investigadores ya que constituye el único antídoto contra el olvido, y por ello, su divulgación social debe ser obligada.

En la exploración de la construcción de la idea de patrimonio industrial podemos concluir que los bienes y los paisajes industriales han sido objeto de una apreciación dual en el curso de la historia situando la frontera entre la repulsa y la aceptación en el momento del cese de la actividad o de su obsolescencia, en el momento en que surge la pérdida, y el temor a la desaparición irrevocable. La globalización y homologación de situaciones en relación al patrimonio industrial es una tendencia de las industrias culturales de la denominada "sobremodernidad" (Augé, 2003: 59). El riesgo mayor es la trivialización, la conversión de las cosas en espectáculo o en simulacro como denunciaba Baudrillard, a lo que se opone la autenticidad de la no intervención y la poética romántica de la ruina industrial también reivindicable como acto cultural.

No obstante, es preciso continuar con un debate abierto centrado en el plano programático, funcional y en el de la intervención física sobre los paisajes y bienes industriales en el que interrogarse sobre la desintegración del contexto urbanístico y sobre la desintegración y pérdida de significado del propio bien por el abandono prolongado, sobre el riesgo de las intervenciones de rehabilitación poco afortunadas que ignoran la oportunidad y compatibilidad de los nuevos usos programados -también a nivel social-, con las características tipológicas, espaciales y constructivas del edificio industrial dignas de conservación, planteándose un difícil equilibrio entre conservación-transformación implícito en la naturaleza de lo construido. La imposibilidad de instalar determinados usos que requieren instalaciones técnicas y espacio habitable en edificios-máquina y estructuras como altos hornos los aboca a su disfrute hedonista cultural y turístico. La conservación para usos culturales es en ocasiones la única vía para la conservación de los valores tecnológicos, históricos, económicos, y culturales de determinadas estructuras y paisajes. Los paisajes históricos de la industria constituyen una 
realidad efímera por el carácter dinámico de la ciudad y el territorio, por ello la congelación de los mismos resulta inviable.

La representación de la tecnología y la industria están en continua renovación al renovarse los sistemas productivos y las fuentes de energía, los cuales alumbran nuevas formas arquitectónicas, estructuras y paisajes cuya valoración histórica demanda una nueva confrontación reflexiva sobre sus impactos en paralelo a su recepción estética y su posible conservación patrimonial futura.

\section{Bibliografía.}

AA.Vv. (2007) Plan Nacional de Patrimonio Industrial, en Bienes Culturales. Revista del Instituto del Patrimonio Histórico Español, 7.

AUGÉ, M. (2003), El tiempo y las ruinas. Barcelona, Gedisa.

BANHAM, R. (1989), La Atlántida de Hormigón: edificios industriales en los Estados Unidos y arquitectura moderna europea, 1900-1925. Madrid, Nerea.

BEHNE, A. (1994), La Construcción funcional moderna (edición a cargo de J. A. Sanz Esquide). Barcelona, Ediciones del Serbal, Demarcación de Barcelona. Colegio de Arquitectos de Cataluña.

BenÉvolo, L. (1990), Historia de la Arquitectura Moderna. Gustavo Gili. Barcelona ( $6^{\mathrm{a}}$ ed. ampliada).

BENITO, P. (1993). "El problema de las ruinas industriales en Europa”. Boletín de Información sobre las Comunidades Europeas. Oviedo: Universidad de Oviedo y Principado de Asturias, pp. 22-26.

— (2012). "Territorio, paisaje y herencia industrial: debates y acciones en el contexto europeo", en Documents d'Anàlisi Geogràfica, vol. 58/3, pp. 443-457.

BONIFACIO, P. (1999), "Producción en serie, territorio, comunidad: Yvrea y Adriano Olivetti", en Arquitectura e Industria Modernas. Actas Segundo Seminario DOCOMOMO Ibérico. Sevilla 11-13 de noviembre de 1999, pp. 191-197.

CAPEL, H., (2002), La morfología de las ciudades. I. Sociedad, cultura y paisaje urbano. Barcelona, Ediciones del Serbal.

CONSEJO De Europa (2000), Convenio Europeo del Paisaje. Florencia.

CHOAY, F., (1983), El Urbanismo, utopías y realidades. Barcelona, Lumen, $3^{\mathrm{a}} \mathrm{ed}$.

DANESI, S. (1976), “Joy in labour”, Casabella Continuità, no 414, pp.16-23. 
DANIELS, S. (2000), Humphry Repton. Landscape Gardening and the Geography of Georgian England. New Haven, London Yale University Press.

DARLEY, G. (2010), La fábrica como arquitectura. Barcelona, Reverté.

DETHIER, Jean; GUIHEUX, Alain (ed.) (1994), Visiones urbanas. Europa 1870-1993. La ciudad del artista. La ciudad del arquitecto. Barcelona, Centro de Cultura Contemporània de Barcelona, Electa.

De MiCHELI, M. (1988), Las vanguardias artísticas del siglo XX. Madrid: Alianza.

FACHGEBIET STÄDTEBAU, STADTGESTALTUNG UND BAULEITPLANUNG, FAKULTÄT RAUMPLANUNG, TU DORTMUND (Eds) (2008), International Building Exhibition Emscher Park. The projects 10 years later. Essen, Klartex Verlag.

FERNÁNDEZ ÁGUEDA, B. (2009), Evolución urbana y memoria de la ciudad industrial. Futuros para la ciudad de Detroit. Madrid, Cuadernos de Investigación Urbanística, marzo-abril 2009. Instituto Juan de Herrera.

FusCO, R. de (1976): La idea de arquitectura. Historia de la crítica desde Viollet a Persico. Barcelona, Gustavo Gili.

García BrañA, C., LANDrove, S., TOSTOES, A., (2005): La arquitectura de la industria, 1925-1965. Barcelona, Fundación DOCOMOMO Ibérico.

GARCÍA MERINO, L. V. (1982). "Los problemas ambientales del patrimonio industrial. Reflexiones sobre el caso de la Ría de Bilbao". I Jornadas sobre la protección y revalorización del patrimonio industrial. Bilbao: Departamento de Cultura del Gobierno Vasco.

GARNIER, T. (1990), Une cité industrielle. New York, Rizzoli.

KAUfMAN, E. N., (2004), "The Architectural Museum from World's Fair to Restoration Village", en CARbONELl Messias, B. (Ed.), Museum Studies. An Anthology of Contexts. Malden, Oxford, Blackwell Publishing, pp. 283-284.

MADERUELO, J. (Ed.) (2004), William Gilpin: tres ensayos sobre la belleza pintoresca. Madrid, Abada Editores.

MiNISSI, F., RANELLUCCI, S. (1992): Museografia. Roma. Bonsignore.

Moya Pellitero, A.M. (2011), La Percepción del paisaje urbano. Madrid, Biblioteca Nueva.

MuMFORD, L. (2012): La Ciudad en la Historia. Sus orígenes, transformaciones y perspectivas. Logroño, Pepitas de Calabaza.

PARDO ABAD, C. (2004), Vaciado Industrial y nuevo paisaje urbano en Madrid. Antiguas fábricas y renovación de la ciudad. Madrid, Ediciones La Librería. 
PIZZA, A., PLA, M. (2002), Viena-Berlín. Teoría, arte y arquitectura entre los siglos XIX y XX. Barcelona: ETSAB, Edicions de la UPC.

RICHARDS J. M. (1958), The Functional Traditional in Early Industrial Buildings. London, Architectural Press.

Rivera Blanco, J. (2011), "Paisaje, Patrimonio y Caminos a Santiago", Maderuelo, J. y Rivera Blanco, J., Arquitectura: paisaje y patrimonio en la Comunidad de Madrid. Madrid: Universidad de Alcalá, pp. 121-134.

SETA, C. De (2002), La Ciudad europea del siglo XIV al XX. Madrid, Ed. Istmo, Madrid.

SOBRINO SIMAL, J. (1996), Arquitectura Industrial en España 1830-1990, Madrid, Cátedra.

TANDY, C. (1979). Industria y paisaje. Madrid: Instituto de Estudios de la Administración Local.

TUPITSYN, M. (2002), Malevich y el cine. Barcelona, Fundación La Caixa.

ZWEITE, A. (2005), "La propuesta de Bernd y Hilla Becher sobre la forma de mirar: diez ideas clave", en Bernd E Hilla Becher "Tipologías". Madrid, Fundación Telefónica, pp. 7-35. 